\title{
HuR Mediates Changes in the Stability of AChR $\beta$-Subunit mRNAs after Skeletal Muscle Denervation
}

\author{
Olivier R. Joassard, ${ }^{1}$ Guy Bélanger, ${ }^{1}$ Jennifer Karmouch, ${ }^{2}$ John A. Lunde, ${ }^{1}$ Anu H. Shukla, ${ }^{1}$ Angèle Chopard, ${ }^{1}$ \\ Claire Legay, ${ }^{2}$ and Bernard J. Jasmin ${ }^{1}$ \\ ${ }^{1}$ Department of Cellular and Molecular Medicine and Centre for Neuromuscular Disease, Faculty of Medicine, University of Ottawa, Ottawa, Ontario K1H \\ 8M5, Canada, and 2CESEM, CNRS UMR 8194, University of Paris Descartes, F75270 Paris Cédex, France
}

Acetylcholine receptors (AChRs) are heteromeric membrane proteins essential for neurotransmission at the neuromuscular junction. Previous work showed that muscle denervation increases expression of AChR mRNAs due to transcriptional activation of AChR subunit genes. However, it remains possible that post-transcriptional mechanisms are also involved in controlling the levels of AChR mRNAs following denervation. We examined whether post-transcriptional events indeed regulate AChR $\beta$-subunit mRNAs in response to denervation. First, in vitro stability assays revealed that the half-life of AChR $\beta$-subunit mRNAs was increased in the presence of denervated muscle protein extracts. A bioinformatics analysis revealed the existence of a conserved AU-rich element (ARE) in the $3^{\prime}$-untranslated region (UTR) of AChR $\beta$-subunit mRNA. Furthermore, denervation of mouse muscle injected with a luciferase reporter construct containing the AChR $\beta$-subunit 3'UTR, caused an increase in luciferase activity. By contrast, mutation of this ARE prevented this increase. We also observed that denervation increased expression of the RNA-binding protein human antigen $\mathrm{R}$ (HuR) and induced its translocation to the cytoplasm. Importantly, HuR binds to endogenous AChR $\beta$-subunit transcripts in cultured myotubes and in vivo, and this binding is increased in denervated versus innervated muscles. Finally, p38 MAPK, a pathway known to activate HuR, was induced following denervation as a result of MKK3/6 activation and a decrease in MKP-1 expression, thereby leading to an increase in the stability of AChR $\beta$-subunit transcripts. Together, these results demonstrate the important contribution of post-transcriptional events in regulating AChR $\beta$-subunit mRNAs and point toward a central role for HuR in mediating synaptic gene expression.

Key words: AChR $\beta$-subunit mRNA; HuR; p38 MAPK; skeletal muscle denervation

Significance Statement

Muscle denervation is a convenient model to examine expression of genes encoding proteins of the neuromuscular junction, especially acetylcholine receptors (AChRs). Despite the accepted model of AChR regulation, which implicates transcriptional mechanisms, it remains plausible that such events cannot fully account for changes in AChR expression following denervation. We show that denervation increases expression of the RNA-binding protein HuR, which in turn, causes an increase in the stability of AChR $\beta$-subunit mRNAs in denervated muscle. Our findings demonstrate for the first time the contribution of posttranscriptional events in controlling AChR expression in skeletal muscle, and points toward a central role for HuR in mediating synaptic development while also paving the way for developing RNA-based therapeutics for neuromuscular diseases.

\section{Introduction}

Transduction of the acetylcholine signal at the neuromuscular junction $(\mathrm{NMJ})$ to trigger muscle contraction relies on a high density of

Received March 16, 2015; revised June 2, 2015; accepted June 22, 2015.

Author contributions: 0.R.J., G.B., J.K., A.C., C.L., and B.J.J. designed research; O.R.J., G.B., J.A.L., A.H.S., and A.C. performed research; $0 . R . J$. ., G.B., A.C., and B.J.J. analyzed data; $0 . R$.J. and B.J.J. wrote the paper.

This work was supported by grants from the Association Française contre les Myopathies (AFM; to B.J.J. and C.L.), the Canadian Institutes of Health Research (B.J.J.), the Canadian Space Agency (B.J.J.), the Centre National d'Etudes Spatiales (A.C.), and J.O.R. was supported by a postdoctoral fellowship from AFM. We thank Drs Imed Gallouzi and Alex MacKenzie for providing various reagents, members of the Jasmin laboratory for insightful discussions, and Christine Péladeau for technical assistance.

The authors declare no competing financial interests. acetylcholine receptors (AChRs) on the surface of the postsynaptic membrane. AChRs are well characterized heteromeric transmembrane proteins made up of four constitutive subunits $(2 \alpha, 1 \beta$, and 1 $\delta$ ) and one variable $\gamma$ subunit that switches to $\varepsilon$ during muscle development to form adult AChRs (Mishina et al., 1986; Duclert and

Correspondence should be addressed to Dr Bernard J. Jasmin, Department of Cellular and Molecular Medicine Faculty of Medicine, University of Ottawa, 451 Smyth Road, Ottawa, ON K1H 8M5, Canada. E-mail: jasmin@uottawa.ca.

A. Chopard's present addresss: Université de Montpellier, INRA, UMR866 Dynamique Musculaire et Métabolisme, F-34060, Montpellier, France.

DOI:10.1523/JNEUROSCI.1043-15.2015

Copyright $\odot 2015$ the authors $\quad 0270-6474 / 15 / 3510949-14 \$ 15.00 / 0$ 
Changeux, 1995; Missias et al., 1996). Over the last 3 decades, considerable efforts have been invested to understand how the highly localized expression of AChRs within the postsynaptic apparatus occurs (Sanes and Lichtman, 2001). Overall, such an accumulation of AChRs may be seen as a two-step process. First, myogenesis is initially marked by a rapid burst of AChR synthesis with the subsequent clustering of these newly synthesized AChRs at sites of nervemuscle contacts. Second, once the synaptic contacts are established, expression of AChRs becomes restricted to synaptic regions of muscle fibers with active repression in extrasynaptic compartments (Willmann and Fuhrer, 2002). The molecular mechanisms regulating expression of AChRs during myogenesis, synapse formation, and at adult NMJs are well understood and thought to mostly involve transcriptional regulatory pathways (J. Tang et al., 1994; Bessis et al., 1995; Koike et al., 1995; Duclert et al., 1996; Tansey et al., 1996; Altiok et al., 1997; Burden and Yarden, 1997; Fischbach and Rosen, 1997; Sandrock et al., 1997; Schaeffer et al., 1998; Massari and Murre, 2000; Macpherson et al., 2006; H. Tang et al., 2006).

Nerve transection, causing skeletal muscle denervation, has been widely used as a convenient experimental system to also study AChR gene regulation. Thus, skeletal muscle denervation markedly increases the level of $\alpha-, \beta-, \delta$-, and $\gamma$-subunit mRNAs (Evans et al., 1987; Goldman et al., 1988; Witzemann, 1989) to different extent depending on the specific muscle, animal species and AChR subunits considered. Such increases in AChR expression in denervated muscle occurs in extrasynaptic regions of muscle fibers and they have largely been attributed also to increased transcriptional rate resulting in a dramatic increase in AChR synthesis which causes acetylcholine supersensitivity (Lomo and Westgaard, 1975; Merlie et al., 1984; Buonanno and Merlie, 1986; Neville et al., 1998).

Despite the overall model of AChR gene regulation which primarily implicates transcriptional mechanisms, it has been proposed that such molecular events cannot fully account for the changes seen in the levels and localization of synaptic mRNAs in muscle cells (Chakkalakal and Jasmin, 2003) and that therefore, other mechanisms are likely involved and essential in regulating AChR expression. The central objective of the current study was to explore whether post-transcriptional mechanisms, operating at the level of mRNA stability, contribute to the changes in AChR mRNAs seen in denervated muscle. In our work, we also examined the putative involvement of the RNA-binding protein (RBP) human antigen $\mathrm{R}(\mathrm{HuR})$ in controlling $\mathrm{AChR}$ mRNA stability in skeletal muscle. Given the central role of the AChR $\beta$-subunit in agrin-induced cytoskeletal anchoring, AChR aggregation (Friese et al., 2007; Borges et al., 2008), and stabilization of newly form AChR clusters (Rudell and Ferns, 2013), and furthermore, considering the fact that the AChR $\beta$-subunit has been shown to be essential for AChR assembly (Quiram et al., 1999), perhaps even constituting a rate-limiting factor in the assembly of pentameric AChRs (Claudio et al., 1989; Saedi et al., 1991), we chose to focus our effort on this specific AChR subunit.

\section{Materials and Methods}

Animal care. Seven-week-old female C57BL/6 mice, purchased from Charles River Laboratories, were maintained in the Animal Care and Veterinary Service of the University of Ottawa under a constant $12 \mathrm{~h}$ light/dark cycle with food and water ad libitum. Experiments were approved by the University of Ottawa Institutional Animal Care and User Committee and were performed in accordance with the established guidelines of the Canadian Council on Animal Care.

Hindlimb surgical denervation and tissue removal. For denervation, mice were anesthetized $<2-3 \%$ isoflurane. The left sciatic nerve was sectioned and, to avoid reinnervation, a $2-3 \mathrm{~mm}$ segment was removed.
Table 1. Oligonucleotide primers used for PCR analysis

\begin{tabular}{|c|c|}
\hline Gene & Primer sequences $5^{\prime}-3^{\prime}$ \\
\hline \multirow[t]{2}{*}{ AChE (Ache; NM_001290010.1) } & Fwd: CGGAGGCTCTCATCAATACTGG \\
\hline & Rev: GGGACCCCGTAAACCAGAAAG \\
\hline \multirow[t]{2}{*}{ AChR $\beta$-subunit (Chrnb1; NM_009601.4) } & Fwd: CATCATCGCTCACCCCAC \\
\hline & Rev: ACGGTCCACAACCATGGC \\
\hline \multirow[t]{2}{*}{$\beta$-Actin (Actb; NM_007393.3) } & Fwd: CCCTGTATGCCTCTGGTCGT \\
\hline & Rev: ATGGCGTGAGGGAGAGCAT \\
\hline \multirow[t]{2}{*}{ GAPDH (Gapdh; NM_008084.3) } & Fwd: GGGTGTGAACCACGAGAAAT \\
\hline & Rev: CCTTCCACAATGCCAAAGTT \\
\hline \multirow[t]{2}{*}{ HuR (Elavl1; NM_010485.3) } & Fwd: CAGAGGTCATCAAAGATGC \\
\hline & Rev: ATCCCACTCATGTGATCTAC \\
\hline \multirow[t]{2}{*}{ Myogenin (Myog; NM_031189.2) } & Fwd: TCACATAAGGCTAACACCCAG \\
\hline & Rev: GGAATTCGAGGCATATTATGA \\
\hline \multirow[t]{2}{*}{ 18S ribosomal RNA (Rn18s; NR_003278.3) } & Fwd: CGCCGCTAGAGGTGAAATC \\
\hline & Rev: CCAGTCGGCATCGTTTATGG \\
\hline
\end{tabular}

Primers were designed using Primer 3 software from gene sequences obtained from GenBank. Primer specificity was determined using a BLAST search.

The skin was then closed with sterile clips. The contralateral leg remained innervated and served as a control. Three days after denervation, mice were killed and tibialis anterior (TA) muscles were excised and immediately frozen in liquid nitrogen or, embedded in Tissue-Tek OCT Compound (Sakura Finetek) and frozen in melting isopentane precooled with liquid nitrogen. All muscles samples were stored at $-80^{\circ} \mathrm{C}$ for subsequent analyses.

$R N A$ isolation and $R T-q P C R$. Total RNA was extracted from TA muscles using TriPure isolation reagent (Roche Diagnostics) as per the manufacturer's recommendations. TriPure-extracted RNA was treated for $1 \mathrm{~h}$ with DNase I (Invitrogen) to eliminate possible genomic DNA contamination. Real-time quantitative PCR was performed on reverse transcribed RNA using the QuantiTect SYBR Green PCR kit (Qiagen) on an MX3005p real-time PCR system (Stratagene). The selected forward and reverse primer sequences are listed in Table 1 . All reactions were performed in duplicate. All mRNAs of interest used the same cycling parameter: the thermal conditions consisted of an initial denaturation step at $95^{\circ} \mathrm{C}$ for $10 \mathrm{~min}$, followed by 40 cycles of denaturation at $95^{\circ} \mathrm{C}$ for $15 \mathrm{~s}$, annealing at $60^{\circ} \mathrm{C}$ for $30 \mathrm{~s}$, and extension at $72^{\circ} \mathrm{C}$ for $30 \mathrm{~s}$, and a final melting curve. Given that skeletal muscle denervation differentially affects the expression levels of house-keeping genes (Nakao et al., 2015), the expression of the gene of interest in the denervation experiments was normalized using the geometric mean of multiple reference genes [glyceraldehyde-3-phosphate dehydrogenase (GAPDH), $18 \mathrm{~S}$ ribosomal RNA and $\beta$-actin] as previously recommended (Vandesompele et al., 2002). Otherwise, $18 \mathrm{~S}$ ribosomal RNA was used as housekeeping gene for the in vitro experiments.

In vitro stability assays. Proteins extraction and mRNA degradation assays were performed as described previously (Chakkalakal et al., 2008). Briefly, proteins were extracted from $3 \mathrm{~d}$ denervated or control TA muscles using $500 \mu \mathrm{l}$ of a homogenization buffer $\left(10 \mathrm{mmol} \cdot \mathrm{L}^{-1}\right.$ Tris, $\mathrm{pH} 8.0$, $10 \mathrm{mmol} \cdot \mathrm{L}^{-1} \mathrm{KCl}, 1.5 \mathrm{mmol} \cdot \mathrm{L}^{-1} \mathrm{MgCl}_{2}, 2.5 \%$ IGEPAL CA-630) containing protease inhibitor complete mini-tablets as per the manufacturer's recommendations (Roche Diagnostics). Protein extracts were centrifuged for $10 \mathrm{~min}$ at $3500 \times \mathrm{g}$. After discarding the supernatant, pellets were subsequently vortexed and incubated on ice for $20 \mathrm{~min}$ in $100 \mu$ l extraction buffer $\left(20 \mathrm{mmol} \cdot \mathrm{L}^{-1}\right.$ Tris, $\mathrm{pH} 8.0,450 \mathrm{mmol} \cdot \mathrm{L}^{-1}$ $\mathrm{NaCl}, 10 \mathrm{mmol} \cdot \mathrm{L}^{-1} \mathrm{EDTA}$, and protease inhibitor complete minitablets). After incubation, the pelleted fractions were centrifuged at $14,000 \times g$ for $10 \mathrm{~min}$ and the supernatants (enriched in nuclear and cytoskeletal fractions) were collected and used for in vitro stability assays.

The RNA used in these assays was isolated from 3-d-old differentiated C2C12 myotubes using TriPure reagent (Roche Diagnostics). Degradation assays were performed by adding $0.2 \mu \mathrm{g} \cdot \mu \mathrm{l}^{-1}$ of total RNA from C2C12 cells to $0.25 \mu \mathrm{g} \cdot \mu \mathrm{l}^{-1}$ of TA muscle protein extracts and by incubating these two components into a degradation buffer $(10 \mathrm{mmol}$. $\mathrm{L}^{-1}$ Tris pH 7.4, $10 \mathrm{mmol} \cdot \mathrm{L}^{-1} \mathrm{KOAc}, 2 \mathrm{mmol} \cdot \mathrm{L}^{-1} \mathrm{MgOAc}, 2 \mathrm{mmol} \cdot$ $\mathrm{L}^{-1}$ DTT, $0.1 \mathrm{mmol} \cdot \mathrm{L}^{-1}$ Spermine, $1 \mathrm{mmol} \cdot \mathrm{L}^{-1} \mathrm{ATP}, 0.4 \mathrm{mmol} \cdot \mathrm{L}^{-1}$ GTP, $10 \mathrm{mmol} \cdot \mathrm{L}^{-1}$ Phosphocreatine, $40 \mathrm{U} / \mathrm{ml}$ creatine phosphokinase, 
$80 \mathrm{U}$ SUPERNasin) for $20 \mathrm{~min}$ at $37^{\circ} \mathrm{C}$. Time 0 was taken as RNA incubated in the degradation buffer without protein extracts. The reactions were stopped at different time intervals by addition of $250 \mu \mathrm{l}$ of Trizol. The RNA was then precipitated with isopropanol in the presence of $1 \mu \mathrm{l}$ of glycogen RNA grade (R0551, Thermo Fischer Scientific) as a carrier. The amount of AChR $\beta$-subunit and $18 \mathrm{~S}$ transcripts remaining at each time point was determined by RT-qPCR analysis. Values were then plotted on a semi-logarithmic scale as a function of time. Four separate experiments were conducted, using four different TA muscle extracts. Half-life values were then determined relative to appropriate controls for each individual experiment. Relative half-life values were averaged and compared between samples.

Plasmid preparation and electrotransfer of plasmid DNA. Escherichia coli strain DH5 $\alpha$ was transformed with the plasmids $3^{\prime}$-untranslated region (UTR)-AChR $\beta$-subunit WT or 3'UTR-AChR $\beta$-subunit mutedAU-rich element (ARE) into pmirGLO luciferase vector using the heat shock method. Point mutations were performed with the QuikChange mutagenesis kit (Stratagene), according to the manufacturer instructions. The resulting mutations were confirmed by sequencing. Plasmid DNA was prepared using the Qiagen Mega-prep kit guidelines. Briefly, transformed bacteria colonies were selected for ampicillin resistance on LB growth plates. After selection and inoculation of a single colony in LB, the culture was grown for $12-16 \mathrm{~h}$ at $37^{\circ} \mathrm{C}$ under vigorous shaking. After assessment of their purity in a $1 \%$ agarose gel electrophoresis, the bacterial cells were harvested by centrifugation and the pellet was resuspended in the appropriate buffers. The suspension was then placed on a column and allowed to drain by gravity flow. After several washes, the plasmid DNA was eluated and precipitated with isopropanol. Mixed gently, the precipitated plasmid DNA was immediately centrifuged and the obtained pellet was washed with ethanol. Finally, the DNA pellet was air dried and redissolved in $500 \mu \mathrm{l}$ of $0.9 \%$ saline solution. Plasmid DNA concentration was measured using a spectrophotometer (Pharmacia GeneQuant) at $260 \mathrm{~nm}$.

Under isoflurane anesthesia, TA muscles of mice were injected with 30 $\mu \mathrm{l}$ of the solution containing either the $3^{\prime} \mathrm{UTR}$-AChR $\beta$-subunit WT or the 3'UTR-AChR $\beta$-subunit mutated-ARE constructs. The injected solution contained a concentration of DNA equal at $1 \mu \mathrm{g} \cdot \mu \mathrm{l}^{-1}$. Thirty seconds after injection, six pulses $(20 \mathrm{~ms}, 50 \mathrm{~mA}$ ) were delivered to the muscles using an electroporator. In these experiments, a $\beta$-galactosidase cDNA plasmid (pCMV $\beta$-galactosidase containing the cDNA of the $E$. coli $\beta$-galactosidase gene driven by the cytomegalovirus CMV enhancer and early promoter elements) was coinjected and used to monitor transduction efficiency and to normalize the luciferase data. Mice were then allowed to recover for $7 \mathrm{~d}$ before denervation.

Luciferase reporter assays. The activity of luciferase was determined using the Luciferase Reporter Assay kit (Promega) according to the manufacturer's instructions. Briefly, $300 \mu \mathrm{l}$ of $1 \times$ Passive Lysis Buffer was added to powdered TA muscles and homogenized at $4^{\circ} \mathrm{C}$. Homogenates were subjected to three freeze-thaw cycles and centrifuged at $10,000 \times g$ for $10 \mathrm{~min}$ at $4^{\circ} \mathrm{C}$. Measurements were performed using a luminometer (Lumat LB 9507; Berthold Technologies).

$\beta$-Galactosidase activity assays. The $\beta$-galactosidase activity was assayed using the $\beta$-Galactosidase Enzyme Assay System from Promega, according to the manufacturer's instructions. Briefly, $50 \mu \mathrm{l}$ of assay $2 \times$ buffer $\left(2 \mathrm{mmol} \cdot \mathrm{L}^{-1} \mathrm{MgCl}_{2}, 100 \mathrm{mmol} \cdot \mathrm{L}^{-1} \beta\right.$-mercaptoethanol, and $1.33 \mathrm{mg} \cdot \mathrm{ml}^{-1} o$-nitrophenyl- $\beta$-D-galactopyranoside) were added to 20 $\mu \mathrm{l}$ of homogenates on a 96 -well plate. The plate was then incubated at $37^{\circ} \mathrm{C}$ for $1 \mathrm{~h}$. The reaction was stopped by adding $150 \mu \mathrm{l}$ of $1 \mathrm{~mol} \cdot \mathrm{L}^{-1}$ sodium carbonate solution to each well. The absorbance of the samples was measured at $420 \mathrm{~nm}$ with a plate reader (Synergy, BioTek). Absorbance was plotted by linear regression against a $\beta$-galactosidase standard curve.

Protein isolation and immunoblotting. Proteins were extracted from powdered TA muscles by homogenization at $4^{\circ} \mathrm{C}$ in $1 \times$ Passive Lysis Buffer (Promega). Homogenates were centrifuged at $12,000 \times g$ for 20 $\min$ at $4^{\circ} \mathrm{C}$, and the resulting supernatants collected and stored in aliquots at $-80^{\circ} \mathrm{C}$. Total protein content was measured using the bicinchoninic acid protein assay kit (Pierce BCA Protein Assay kit, Thermo Fischer Scientific) with bovine serum albumin as a standard. For Western blotting, equal amounts of proteins $(30 \mu \mathrm{g})$ were loaded on $10 \%$ SDSpolyacrylamide gels. Proteins were transferred onto $0.2 \mu \mathrm{m}$ nitrocellulose membranes. Systematically, gel loading and transfer efficiency were ascertained by Ponceau S and Coomassie Blue staining, respectively. Membranes were then blocked with 5\% skim milk in PBS containing also $0.05 \%$ Tween to avoid nonspecific binding, and they were incubated overnight at $4^{\circ} \mathrm{C}$ with primary antibodies. Blots were probed using antibodies (1:1000) directed against $\beta$-actin, HuR (Santa Cruz Biotechnology), phospho-p38 (Thr180/Tyr182), total p38 and phosphoMKK3(S189)/MKK6(S207; Cell Signaling Technology), total MKK3/6 (R\&D Systems), MKP-1 (Millipore), MKP-5 and lamin A+C (Abcam), and $\alpha$-tubulin (Sigma-Aldrich). After washing with PBS containing $0.05 \%$ Tween, membranes were incubated with anti-mouse IgG lightchain-specific horseradish peroxidase-conjugated secondary antibody (Jackson ImmunoResearch Laboratories). After $3 \times 5$ min washes with PBS with $0.05 \%$ Tween, chemiluminescent signals were revealed using ECL reagents (Pierce ECL Western Blotting Substrat, Thermo Fischer Scientific). The x-ray films (Thermo Fisher Scientific) were finally scanned and quantified with ImageJ analysis software (National Institutes of Health). $\beta$-Actin or $\alpha$-tubulin served to verify equal protein loading among samples.

Subcellular fractionation. Control and $3 \mathrm{~d}$ denervated TA muscles were powdered in liquid nitrogen with a mortar and pestle. Subcellular fractionation was performed as previously described (Dimauro et al., 2012) with tubulin and lamin $\mathrm{A}+\mathrm{C}$ used as cytoplasmic and nuclear fraction markers, respectively.

Immunofluorescence. TA muscle cross-sections $(10 \mu \mathrm{m})$ were cut using a microtome at $-20^{\circ} \mathrm{C}$ and processed for immunofluorescence with the HuR (Santa Cruz Biotechnology) and laminin (Sigma-Aldrich) antibodies. Cross-sections were also stained with AlexaFluor 488-coupled $\alpha$-bungarotoxin (B13422, Life Technologies) to visualize AChRs. The MOM Immunodetection Kit (Vector Laboratories) was used to localize the primary antibodies. Slides containing tissue sections were mounted with Vectashield mounting medium (Vector Laboratories). Tissue sections were visualized using a Zeiss AxioImager.M2 fluorescent microscope and high-resolution images were acquired using Image (NIH).

RNA immunoprecipitation. RNA immunoprecipitation (RNA-IP) was performed as recently described (Amirouche et al., 2013a). Briefly, cultured $\mathrm{C} 2 \mathrm{C} 12$ myotubes were crosslinked with $1 \%$ formaldehyde in PBS for $10 \mathrm{~min}$ at room temperature. The reaction was stopped with a wash in ice-cold PBS. Equal amounts of whole-cell extracts were immunoprecipitated with Protein A agarose-bound rabbit anti-HuR antibody beads (Sigma-Aldrich) or rabbit IgG (Santa Cruz Biotechnology) as control. The beads were washed with modified RIPA buffer supplemented with protease and phosphatase inhibitors (Roche Diagnostics) and heated to $70^{\circ} \mathrm{C}$ for $1 \mathrm{~h}$ to reverse crosslinking. RNA was extracted from the immunoprecipitates using Tripure Reagent (Roche Diagnostics). Real-time RT-qPCR was performed as described above. RIP assays using TA innervated and denervated muscles were performed as previously described (Nechama et al., 2008).

Cell culture, plasmids, and transfection. Mouse C2C12 muscle cells (American Type Culture Collection) were plated in DMEM supplemented with $20 \%$ fetal bovine serum (MultiCell, Wisent), $1 \%$ penicillinstreptomycin $(\mathrm{P} / \mathrm{S})$, and $1 \%$ L-glutamine (Thermo Fischer Scientific) at $37^{\circ} \mathrm{C}$ and $5 \% \mathrm{CO}_{2}$ in air in 6-well culture dishes. At $\sim 20-30 \%$ confluency, $\mathrm{C} 2 \mathrm{C} 12$ myoblasts were transfected with si-HuR (kindly provided by Dr Imed Gallouzi, Department of Biochemistry, Goodman Cancer Center, McGill University, Montreal, QC, Canada) using jetPRIME (Polyplus transfection, VWR). This transfection was repeated $24 \mathrm{~h}$ following the first transfection when cells were at $\sim 50-60 \%$ confluency. When cells reached $90-95 \%$ confluency, differentiation was induced for $3 \mathrm{~d}$ in a medium containing DMEM, $2 \%$ horse serum (PAA) and $1 \% \mathrm{P} / \mathrm{S}$. To study the stability of the transcript, cells were treated with the transcriptional inhibitor actinomycin D $\left(5 \mu \mathrm{g} \cdot \mathrm{ml}^{-1}\right.$; Invitrogen Life Technologies) and harvested at 2, 4, 6, or $8 \mathrm{~h}$.

Myotubes were treated for $1 \mathrm{~h}$ with SB203580 (S8307, Sigma-Aldrich) or anisomycin (A9789, Sigma-Aldrich), both at the concentration of 10 $\mu \mathrm{mol} \cdot \mathrm{L}^{-1}$, to either inhibit or activate $\mathrm{p} 38 \mathrm{MAPK}$, respectively. Control cells were incubated with dimethylsulfoxide (D5879, Sigma-Aldrich). In 
A

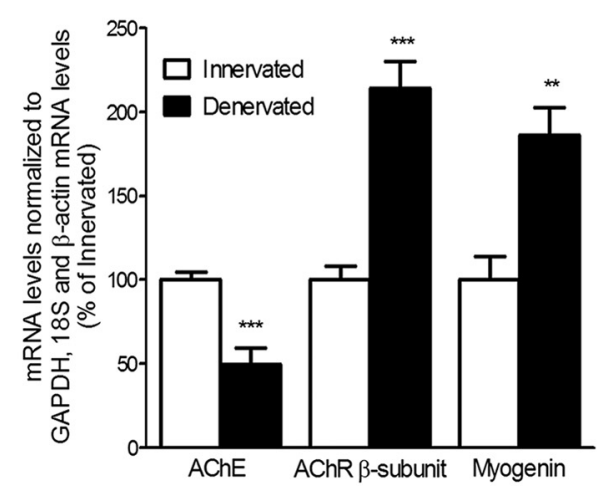

C

Mouse AChR $\beta$-subunit mRNA 3' untranslated region

1565 GGACCCTCCGGTCATTTTTGCCAAATGCTGCAGGTACTCTCAAGCTCAATAGCGCT 1621 TGGCGCTTGTAAGAATCTTGTTTCTGGGAAGACGTTCAAGTGAGACTTGGAGGCTGAGCA 1681 TGGTCCCTTGGACCCACCCGAAATGTCCTTCTACTTATT 1741 CGGT 1801 ACTGTGGCGTCCAGGCTGGTCTCAAACTCCCAACAATGTTACTTCCTTAGCCTAGCAATT

D

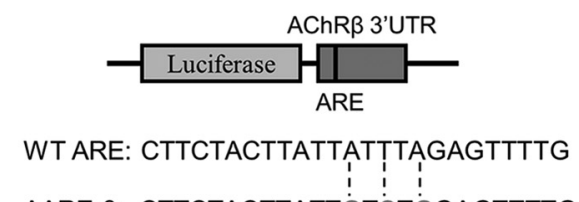

$\triangle$ ARE $\beta$ : CTTCTACTTATTGTĊTGGAGTTTTG
B

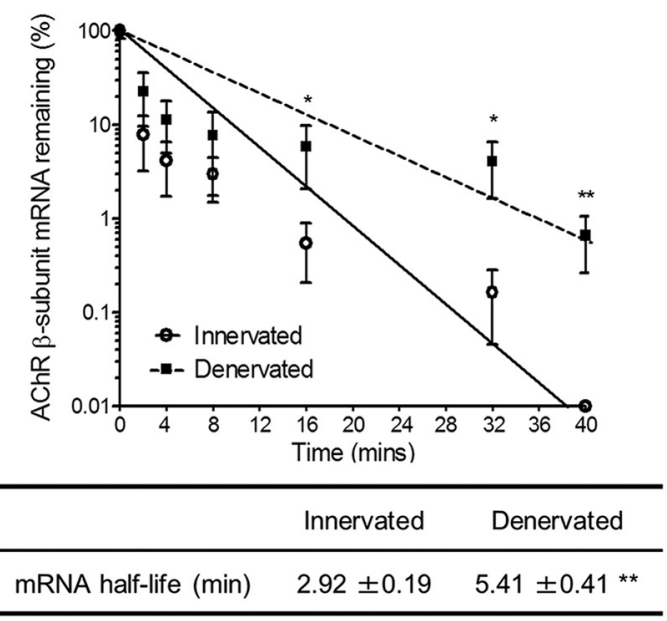

$\mathbf{E}$

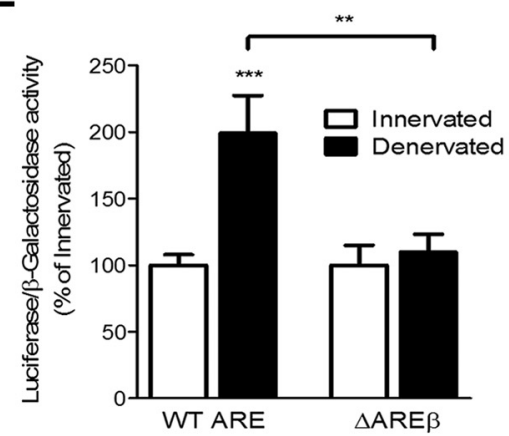

Figure 1. Denervation increases AChR $\beta$-subunit mRNA stability via an ARE site. $A$, Endogenous mRNA levels of AChE, AChR $\beta$-subunit and myogenin following $3 \mathrm{~d}$ of denervation. GAPDH, 185 and $\beta$-actin were used as housekeeping genes (see Materials and Methods). Data are mean $\pm \mathrm{SEM}, n=10-12$ per group. ${ }^{* *} p<0.01$ and ${ }^{* * *} p<0.001$ : significantly different from respective innervated group. $\boldsymbol{B}$, In vitro AChR $\beta$-subunit mRNA stability assays. Quantification of the amounts of $A C h R \beta$-subunit mRNA at each time point, is plotted in a semi-log scale as percentage of RNA seen at time 0.185 was used as a control. ${ }^{*} p<0.05$, and ${ }^{* *} p<0.01$ : significantly different from the innervated group. C, Portion of the $3^{\prime} U T R$ sequence of the mouse AChR $\beta$-subunit transcript with the ARE binding site (ATTTA) highlighted. D, Schematic representation of the construct containing the luciferase reporter followed by the AChR $\beta$-subunit $3^{\prime}$ UTR sequence. The localization of the ARE motif of the AChR $\beta$-subunit is indicated. Below, the ARE motifsequence in WT 3'UTR (WT ARE) and the mutated nucleotides in the ARE motif ( $\triangle$ ARE $\beta$ ) are shown. $E$, Luciferase activity after denervation. Mouse TA muscles were injected and electroporated with the luciferase reporter construct containing either the WT AChR $\beta 3^{\prime}$ UTR (WT ARE) or the mutated AChR $\beta 3^{\prime}$ UTR ( $\triangle$ ARE $\beta$ ). After $7 \mathrm{~d}$, TA muscles were denervated. Three days after denervation, TA muscles were excised and luciferase activity measured. To correct for variations in transduction efficiency, luciferase activity was normalized to $\beta$-galactosidase activity and the results are expressed as a ratio of luciferase/ $\beta$-galactosidase. Data are mean \pm SEM, $n=10-12$ per group. ${ }^{* *} p<0.01$, and ${ }^{* * *} p<0.001$ : significantly different from WT ARE denervated and WT ARE innervated, respectively.

parallel experiments, myotubes were treated for $24 \mathrm{~h}$ with Calcitriol (71820, Cayman Chemical; at the concentrations of 1,20, and $100 \mathrm{nmol}$ $\left.\cdot \mathrm{L}^{-1}\right)$. Control cells were incubated with ethanol. Then, cells were treated with actinomycin D $\left(5 \mu \mathrm{g} \cdot \mathrm{ml}^{-1}\right)$ for $2,4,6$, or $8 \mathrm{~h}$ to inhibit transcription.

In separate experiments, $\mathrm{C} 2 \mathrm{C} 12$ myoblasts at 50\% confluency were transfected for $4 \mathrm{~h}$ with an expression plasmid containing MKK6-EE or pcDNA3.1 (kindly provided by Dr Alex MacKenzie, Apoptosis Research Center, Children's Hospital of Eastern Ontario Research Institute). At 90-95\% confluency, C2C12 cells were differentiated into myotubes for $3 \mathrm{~d}$, and then treated with actinomycin D $\left(5 \mu \mathrm{g} \cdot \mathrm{ml}^{-1}\right)$. Data are from $3 / 4$ independent culture dishes.

Statistical analysis. All values are expressed as mean \pm SEM. Unpaired $t$ tests, as well as one-way ANOVA with Fisher's post hoc tests were used to determine whether differences between the different group means were significant. Statistical analyses were performed using StatView v5.0 (SAS Institute). The $\alpha$-level of significance was set at 0.05 for all comparisons.

\section{Results}

Skeletal muscle denervation increases AChR $\beta$-subunit mRNA stability via an ARE

To determine whether the stability of AChR $\beta$-subunit mRNAs is altered in denervated muscles, we used short-term denervation as an experimental model system. We first examined the levels of several mRNAs $3 \mathrm{~d}$ postdenervation in mouse TA muscles. In this context, we show that denervation induces a $\sim 2$. 1 -fold increase $(p<0.001)$ in the levels of AChR $\beta$-subunit mRNA (Fig. 1A). As control mRNAs for the effects of denervation, we also examined AChE and myogenin mRNAs. As expected, AChE mRNA levels decreased by $\sim 50 \%$ after denervation $(p<0.001)$, whereas those encoding myogenin increased by $\sim 86 \%$ ( $p<0.01$; Fig. $1 A)$, consistent with previous studies (Eftimie et al., 1991; Witzemann and Sakmann, 1991; Maltin et al., 1993; Michel et al., 1994).

To test whether denervation causes a change in the stability of AChR $\beta$-subunit mRNAs, we performed in vitro stability assays (Chakkalakal et al., 2008). The use of such an approach is warranted in this case as treatment of mice with actinomycin D (an approach to study changes in mRNA stability widely used with cultured cells, see below for example) is fraught with difficulties including premature death of the animals shortly (few hours) after actinomycin D injection as previously discussed (Ross, 1995). For the in vitro stability assays, total RNA from 3 d differentiated $\mathrm{C} 2 \mathrm{C} 12$ myotubes was isolated and incubated with protein extracts obtained from innervated or $3 \mathrm{~d}$ denervated TA muscles for different time intervals in a degradation buffer. The amount of $\mathrm{AChR} \beta$-subunit mRNAs remaining at each time 
point was subsequently determined by RT-qPCR and used to calculate mRNA decay kinetics. In these assays, we observed that AChR $\beta$-subunit mRNAs decay at a slower rate in the presence of protein extracts from denervated TA muscle compared with incubation with protein extracts from innervated muscles (Fig. 1B). Quantitative assessment of half-life values revealed that AChR $\beta$-subunit mRNAs degraded at approximatively twice the rate $(p<0.01)$ in the presence of innervated muscle protein extracts indicating that denervation causes an increased in their stability (Fig. 1B). As a control, the analysis of $18 \mathrm{~S}$ transcripts did not reveal any difference $(p>0.05)$ in the rate of degradation upon incubation with innervated or denervated TA muscle protein extracts (data not shown). These results demonstrate therefore, that in addition to transcriptional events, an increase in mRNA stability also contributes to the abundance of AChR $\beta$-subunit transcripts in denervated muscles.

Because stabilizing sequences are often located in the $3^{\prime}$ UTR of transcripts, we screened the sequence of the AChR $\beta$-subunit mRNA for known motifs involved in RNA stabilization/degradation. Specifically, the mouse AChR $\beta$-subunit transcript is 2151 nucleotides (nt) long, contains $1506 \mathrm{nt}$ of coding sequence and a $3^{\prime}$ UTR that is $531 \mathrm{nt}$ long. Bioinformatics analysis using the online resource AREsite (Gruber et al., 2011) revealed that the $\beta$-subunit of the mouse AChR mRNA contains one ARE in its 3'UTR (Fig. 1C) making it an excellent candidate for controlling the stability of this transcript. In addition, sequence comparison across human, orangutan, rat, cow, and mouse revealed that this ARE found in the AChR $\beta$-subunit transcript, is conserved across multiple species.

To evaluate the contribution of the ARE in regulating the abundance of the AChR $\beta$-subunit mRNA upon denervation, we first generated a wild-type and an ARE-mutated form of the mouse full-length $3^{\prime}$ UTR and inserted each one of these downstream of a luciferase reporter gene (3'UTR WT ARE and 3'UTR $\triangle \mathrm{ARE} \beta$, respectively) driven by a constitutively active promoter. The mutated form contains three point mutations in the ARE element (Fig. 1D). We then injected/electroporated mouse TA muscles with luciferase constructs containing either the $3^{\prime}$ UTR WT ARE or the $3^{\prime} \mathrm{UTR} \triangle \mathrm{ARE} \beta$, and denervated $7 \mathrm{~d}$ later. To monitor transduction/electroporation efficiency, luciferase activity was normalized to $\beta$-galactosidase activity. Our results, expressed as a ratio of luciferase to $\beta$-galactosidase activity, revealed $\mathrm{a} \sim 2$-fold increase $(p<0.001)$ in luciferase activity at $3 \mathrm{~d}$ postdenervation with the wild-type $\beta$-subunit $3^{\prime}$ UTR construct (Fig. 1E). By contrast, mutations of the ARE prevented the denervation-mediated increase in luciferase activity $(p<0.01)$ thereby highlighting the critical role of the ARE in mediating changes in $\mathrm{AChR} \beta$-subunit mRNA expression in denervated muscle.

\section{Denervation increases expression of $\mathrm{HuR}$ and promotes its} nuclear-cytoplasmic translocation

Because AChR $\beta$-subunit mRNAs decay at a slower rate in denervated muscle and that the ARE serves as an essential element in regulating transcript levels, we sought to identify a RBP that could play a key role in such a process. In this context, it has been shown that the ubiquitously expressed protein HuR is important in differentiating, cultured muscle cells by interacting with ARE contained in the 3'UTR of transcripts, such as MyoD and myogenin (Figueroa et al., 2003; van der Giessen et al., 2003). Based on this, we therefore wondered whether denervation affects $\mathrm{HuR}$ expression.

Using RT-qPCR, we first observed an increase $(\sim 44 \%)$ in HuR mRNA levels $(p<0.01)$ following $3 \mathrm{~d}$ of denervation of mouse TA muscles (Fig. 2A). To complement this analysis, we also measured by Western blotting, the levels of $\mathrm{HuR}$ protein. Our results show that HuR protein is also increased ( $38 \%$; $p<$ 0.05 ) after denervation (Fig. 2A). During myogenesis, it is known that $\mathrm{HuR}$ is cleaved by caspase 3 leading to the production of a cleavage product (HuR-CP1) known to promote accumulation of HuR in the cytoplasm (Beauchamp et al., 2010). Furthermore, skeletal muscle denervation results in an increase in caspase-3 protein and enzymatic activity (Siu and Alway, 2005, 2006). Thus, we also examined whether denervation increases HuR-CP1 protein level. Western blotting experiments revealed that the levels of HuR-CP1 are significantly increased $(p<0.05) 3 \mathrm{~d}$ after denervation (Fig. 2B).

Increased cytoplasmic levels of HuR have been shown to correlate with its increased activity in ARE-mediated mRNA stability (Wang et al., 2000). To determine whether HuR protein is redistributed to the cytoplasm after denervation to potentially increase the stability of AChR $\beta$-subunit mRNAs, we conducted subcellular fractionation experiments and Western blotting on both nuclear and cytoplasmic fractions. The relative purity of the nuclear and cytoplasmic fractions was first evaluated by monitoring the presence of lamin $\mathrm{A}+\mathrm{C}$ (expressed in nuclei) and tubulin (found in the cytoplasm; Fig. 2C). In these experiments, we noted that HuR protein levels were increased in both nuclear and cytoplasmic fractions after denervation. In fact, we observed a $\sim 2.4$ fold $(p<0.05)$ and $a \sim 2$-fold $(p<0.05)$ increase in HuR in the cytoplasmic and nuclear fractions, respectively (Fig. 2C). Although there is a global increase in the expression of $\mathrm{HuR}$, there appears to be a greater increase in the cytoplasmic fraction as shown by analysis of the cytoplasmic/nuclear ratio in denervated versus innervated muscles (Fig. 2C), suggesting that HuR becomes enriched in the cytoplasm after denervation. Together, these results suggest that the stability of $A C h R \beta$-subunit mRNAs is increased after denervation as a result of an increase in both $\mathrm{HuR}$ expression and in its cytoplasmic accumulation.

To complement these findings, we also performed immunofluorescence experiments using TA muscle cross-sections stained with antibodies against HuR. The data also revealed an accumulation of $\mathrm{HuR}$ in the cytoplasm of muscle fibers $3 \mathrm{~d}$ following denervation (Fig. $3 A$ ), reinforcing the notion that HuR translocates to the cytoplasm after denervation. Colabeling of AChR with $\alpha$-bungarotoxin confirmed an increase in the expression level of AChRs in extrasynaptic regions of denervated muscle fibers (Fig. 3B). Interestingly, we observed excellent extrasynaptic colocalization between AChR and HuR, especially in smaller perhaps more atrophied muscle fibers, indicating enhanced expression of AChRs in fibers with high levels of HuR.

\section{$H u R$ interacts with AChR $\beta$-subunit mRNAs}

To determine whether HuR controls the stability of AChR $\beta$-subunit mRNAs, we first examined whether HuR binds to AChR $\beta$-subunit transcripts in cultured muscle cells. To test this potential HuR-AChR $\beta$-subunit mRNA interaction, we performed RNA-IP experiments with myotubes. After formaldehyde crosslinking and HuR or IgG (used as a negative control) immunoprecipitation, coimmunoprecipitated RNAs were isolated and mRNA levels were determined by RT-qPCR. Our results show that in cultured differentiated muscle cells, HuR binds to endogenous AChR $\beta$-subunit mRNAs ( $p<0.01$; Fig. $4 A$ ).

Based on these results, we also examined whether HuR binds to AChR $\beta$-subunit mRNAs in vivo. Given that the increased HuR expression after denervation is associated with an increased stability of AChR $\beta$-subunit mRNAs, we sought to also demonstrate 
A
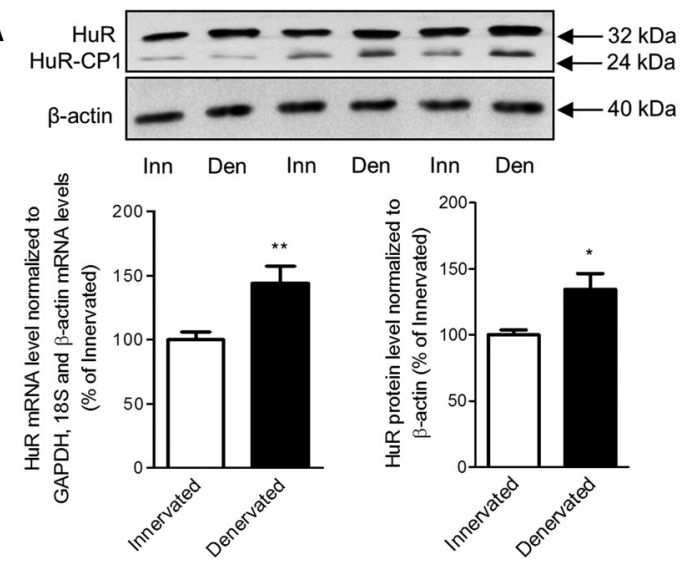

C

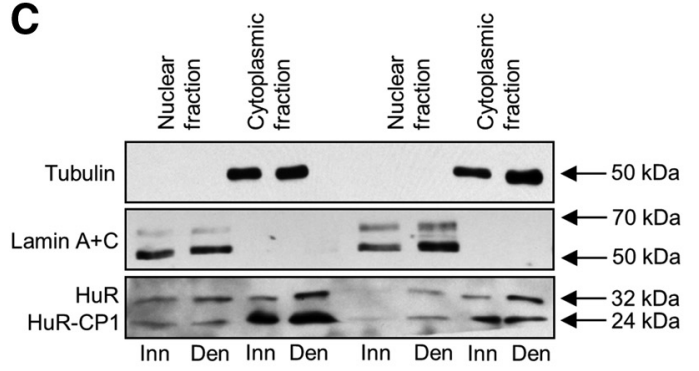

B
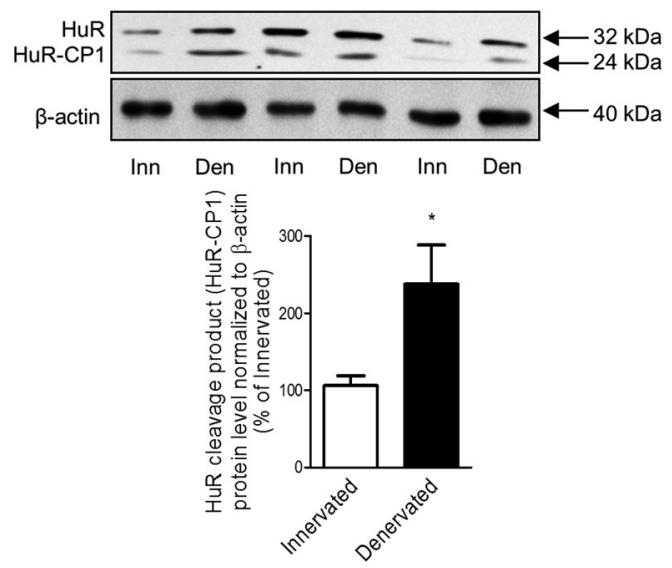

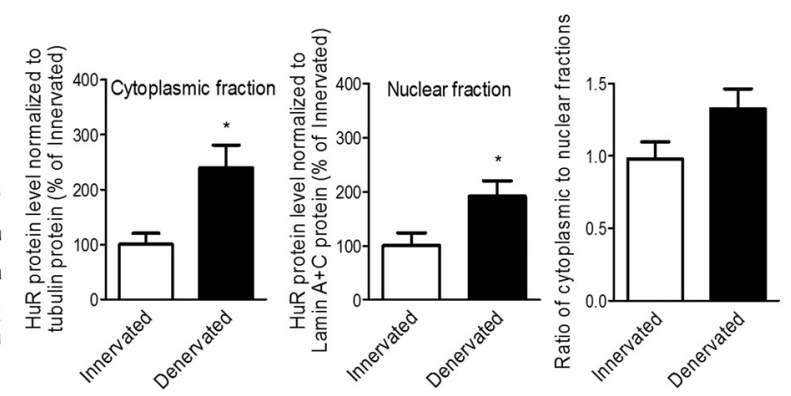

Figure 2. Denervation increases expression of HuR and induces its nuclear-cytoplasmic translocation. $\boldsymbol{A}$, Endogenous mRNA levels of HuR (left) and representative immunoblot (top) and quantification (right) of HuR protein content $3 \mathrm{~d}$ postdenervation. GAPDH, $18 \mathrm{~S}$ and $\beta$-actin were used as housekeeping genes for mRNA level (see Materials and Methods), whereas $\beta$-actin was used as a loading control for protein quantification. $\boldsymbol{B}$, Representative immunoblot of HuR-CP1 protein content (top), and its quantification (bottom). Protein levels of HuR-CP1 were standardized using $\beta$-actin. C, Representative Western blots and their quantification for HuR protein expression from subcellular fractions of innervated (Inn) and denervated (Den) TA muscles. To verify the efficiency of the fractionation protocol, immunoblots were also probed for the cytoplasmic marker, tubulin, and the nuclear marker, lamin $A+C$. The same blots were used to determine HuR protein levels. Data are mean \pm SEM,$n=6-8$ per group. ${ }^{*} p<0.05,{ }^{* *} p<0.01$ : significantly different from respective innervation group.

that the interaction between $\mathrm{HuR}$ and $\mathrm{AChR} \beta$-subunit mRNAs is increased in denervated muscle. To this end, we first crosslinked roughly chopped innervated and denervated muscles with formaldehyde. Equal amounts of whole muscle-cell extracts were then immunoprecipitated with Protein A agarose-bound antiHuR antibody beads or IgG as control. Western blotting revealed the purity of the fraction after immunoprecipitation with the anti-HuR antibody (Fig. 4B, top). After crosslink reversal, the extent of interaction between $\mathrm{HuR}$ and $\mathrm{AChR} \beta$-subunit mRNAs was analyzed by RT-qPCR. As shown in Fig. $4 B$, HuR does interact with AChR $\beta$-subunit mRNAs in innervated skeletal muscle $(p<0.01)$. Importantly, the binding of HuR to AChR $\beta$-subunit transcripts is significantly higher $(\sim 45 \%, p<0.05)$ in denervated versus innervated muscles.

In separate experiments, we examined whether HuR functionally regulates levels of AChR $\beta$-subunit mRNAs and their stability. For this, we used a siRNA directed against HuR (si$\mathrm{HuR}$ ) and transfected $\mathrm{C} 2 \mathrm{C} 12$ myoblasts with this construct. The same transfection was repeated $24 \mathrm{~h}$ later, and cells were then allowed to differentiate for $3 \mathrm{~d}$. Silencing HuR was very efficient because it induced an $\sim 80 \%$ decrease $(p<0.001)$ in HuR protein levels (Fig. $4 C$ ). In these cells, we noticed a significant $(p<$ 0.001 ) reduction in the levels of AChR $\beta$-subunit mRNAs (Fig. 4C).

To complement these experiments, we also determined the half-life of AChR $\beta$-subunit mRNAs in muscle cells transfected with the si-HuR construct. For this, we added the transcriptional inhibitor actinomycin D to cells after their transfection and differentiation. Then, the relative abundance of AChR $\beta$-subunit mRNAs was monitored at $0,2,4,6$, and $8 \mathrm{~h}$. Quantitative deter- mination of half-life values revealed that AChR $\beta$-subunit mRNAs degraded at $\sim 2.3$ times the rate $(p<0.001)$ in the presence of si-HuR (Fig. 4D). As a control, $18 \mathrm{~S}$ transcript decay rates in the same cultured myotubes were not affected $(p>0.05$; data not shown). Altogether, these data indicate that by binding to the transcript, HuR positively regulates expression of AChR $\beta$-subunit mRNAs and their stability.

\section{p38 MAPK signaling regulates AChR $\beta$-subunit mRNA stability} in vitro

An important question raised by the findings described above deals with the signaling events through which $\mathrm{HuR}$ regulates the stability of AChR $\beta$-subunit mRNAs. Previous work in motor neurons showed that anisomycin, an activator of p38 MAPK, causes a p38-dependent cytoplasmic accumulation of $\mathrm{HuR}(\mathrm{Fa}$ rooq et al., 2009). Given this and our results implicating HuR in controlling the stability of AChR $\beta$-subunit mRNAs after denervation, we hypothesized that $\mathrm{p} 38$ MAPK activation in denervated muscles could increase the stability of AChR $\beta$-subunit mRNAs. To examine this, we first treated $\mathrm{C} 2 \mathrm{C} 12$ myotubes with either an activator (anisomycin) or an inhibitor (SB203580) of p38 MAPK signaling. As shown in Fig. $5 A$, anisomycin $\left(10 \mu \mathrm{mol} \cdot \mathrm{L}^{-1}\right)$ increased $(p<0.001)$ by $>40 \%$ the levels of AChR $\beta$-subunit mRNAs. By contrast, inhibition of p38 MAPK with SB203580 (10 $\left.\mu \mathrm{mol} \cdot \mathrm{L}^{-1}\right)$ decreased $(p<0.001)$ expression of AChR $\beta$-subunit transcripts (Fig. $5 A$ ). We also performed stability assays using actinomycin $\mathrm{D}$ and the activator or inhibitor of p38 MAPK. In this case, our results show that the stability of AChR $\beta$-subunit mRNAs is decreased $(p<0.01)$ following p38 MAPK inhibition, whereas p38 MAPK activation increased $(p<0.1)$ 
A
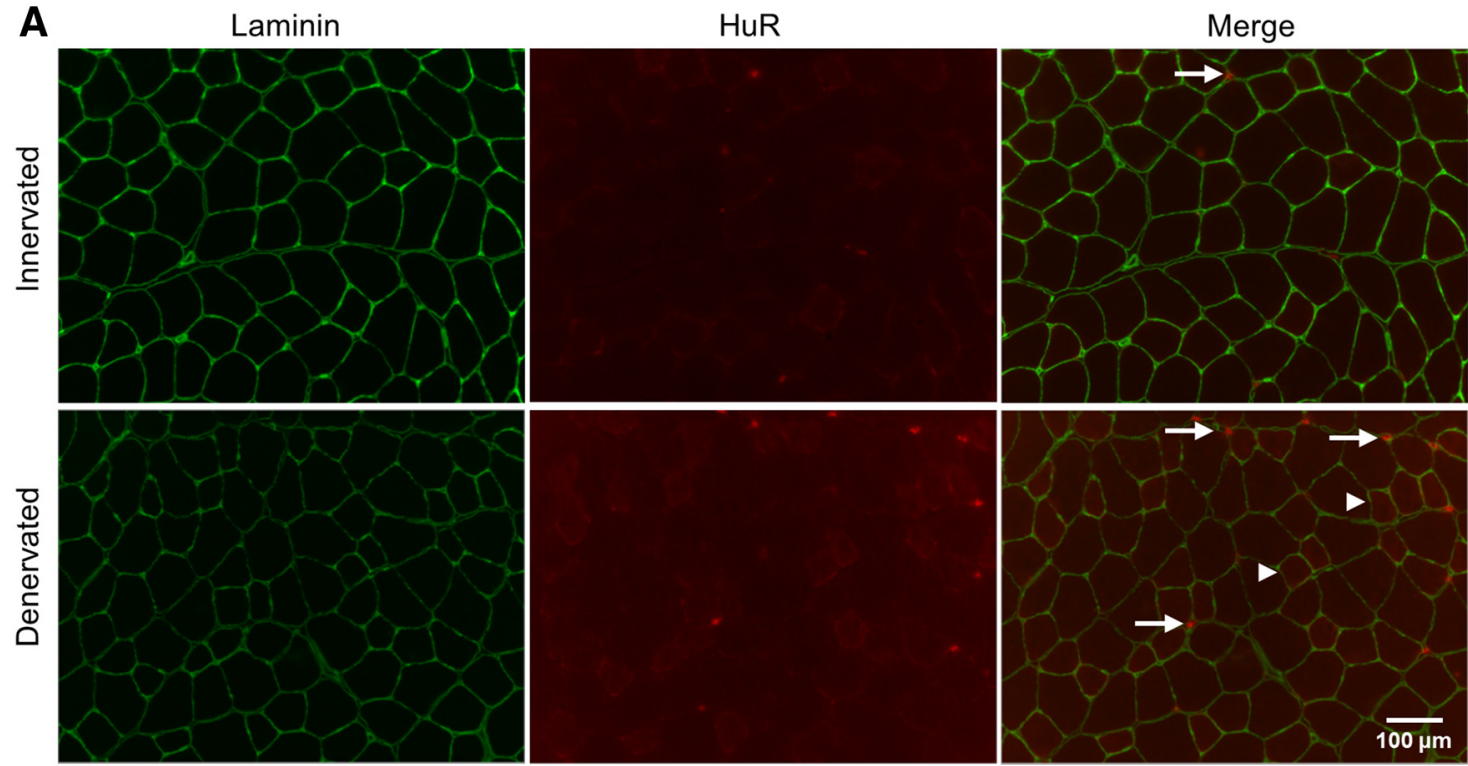

B

HuR

AChR

Merge
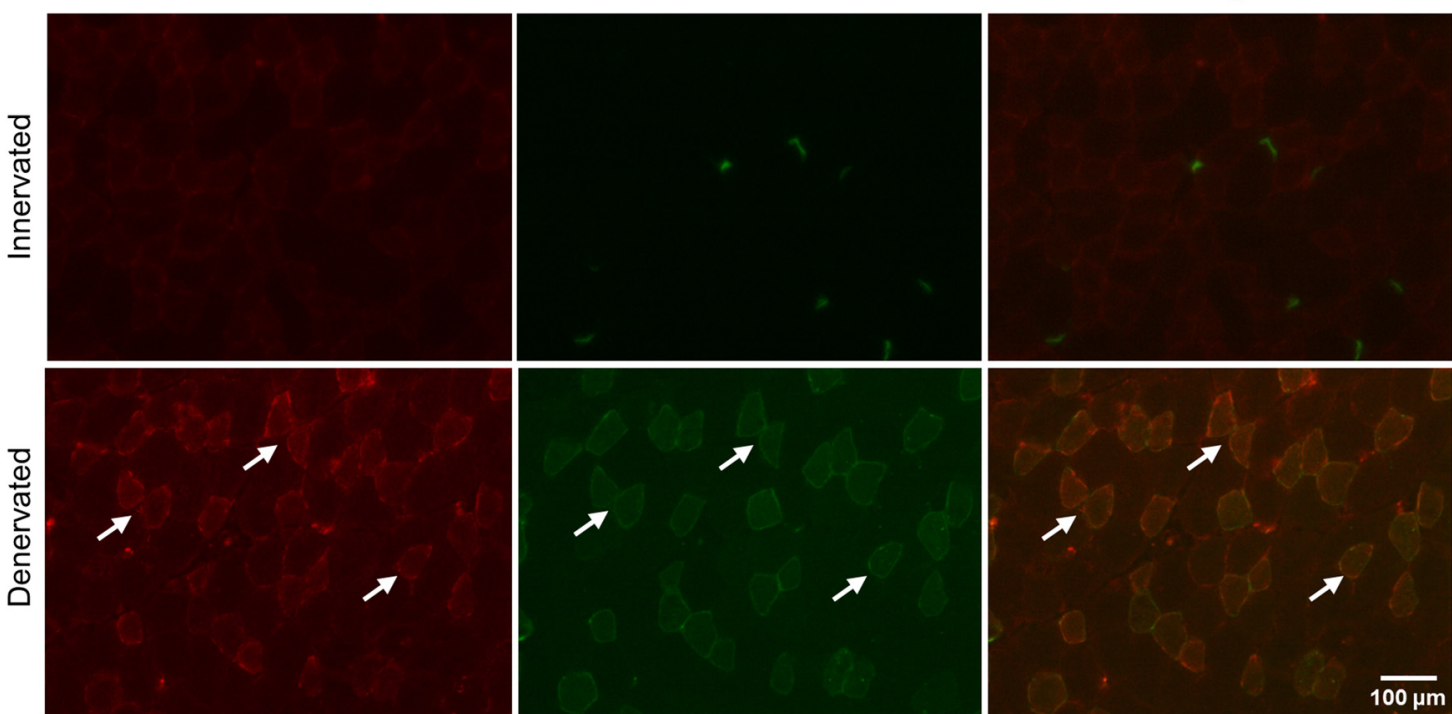

Figure 3. HuR colocalizes with AChRs in denervated muscle fibers. $A$, Representative TA muscle cross-sections stained with antibodies against HuR and laminin to depict the sarcolemma. Solid white arrows show HuR accumulation in nuclei and arrowheads represent HuR accumulation in cytoplasm. $\boldsymbol{B}$, Representative TA muscle cross-sections stained with antibodies against HuR and labeled with $\alpha$-bungarotoxin to identify AChRs. Solid white arrows point to colocalization between HuR and AChR accumulation in extrasynaptic regions of denervated fibers. $n=4$ mice per group. Scale bar, $100 \mu \mathrm{m}$.

transcript stability. Indeed, mRNA half-life measurements showed that AChR $\beta$-subunit mRNAs degraded at $\sim 1.6$ time faster $(p<0.01)$ after p38 MAPK inhibition while we observed $\mathrm{a} \sim 1.4$-fold longer half-life $(p<0.05)$ upon incubation of cells with anisomycin.

To confirm these results, we also treated myotubes with increasing doses of calcitriol $\left(1,20\right.$, and $\left.100 \mathrm{nmol} \cdot \mathrm{L}^{-1}\right)$, another activator of p38 MAPK (Buitrago et al., 2006; 2013; Ronda et al., 2007), for 24 h. Our results show a dose-dependent increase in the phosphorylation status of p38 MAPK (Fig. 5B). Moreover, calcitriol increased $(p<0.05$ ) by $\sim 20 \%$ the endogenous levels of AChR $\beta$-subunit mRNAs. Finally, stability assays using actinomycin D showed an increase $(\sim 1.9$-fold, $p<0.001)$ in the stability of AChR $\beta$-subunit mRNAs. Altogether, these findings obtained with a different p38 MAPK activator nam- ely calcitriol, corroborate our data using anisomycin presented above.

MKK3/6-p38 MAPK regulates AChR $\beta$-subunit mRNA stability Based on these results, we wondered whether there was a change in p38 MAPK activation after denervation. Western blotting revealed that $\mathrm{p} 38 \mathrm{MAPK}$ is indeed activated $(>50 \%, p<0.01)$ after denervation (Fig. $6 A$ ), leading us to further examine the role of p38 MAPK signaling in controlling the stability of AChR $\beta$-subunit mRNAs. First, and to uncover upstream signaling events involved in the activation of $\mathrm{p} 38$ MAPK induced by denervation, we examined expression of the kinases MKK3 and MKK6 which are known to phosphorylate p38 MAPK at threonine 180 and tyrosine 182. Interestingly, we saw after $3 \mathrm{~d}$ of denervation, an increase in the activity of MKK3 and MKK6 $(p<0.05$; Fig. $6 B)$ 
A

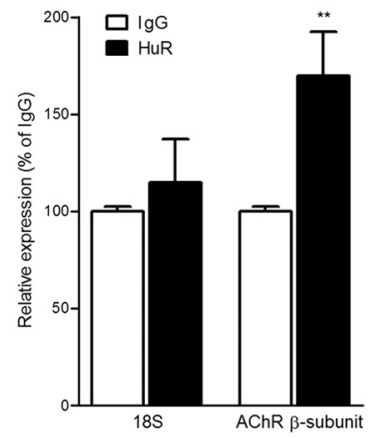

B
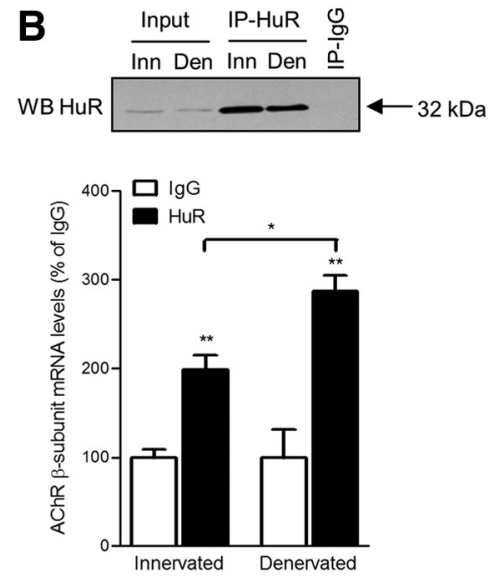
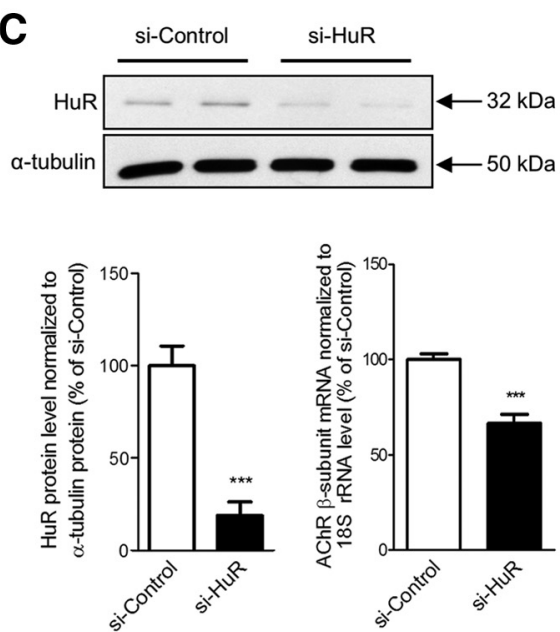

D

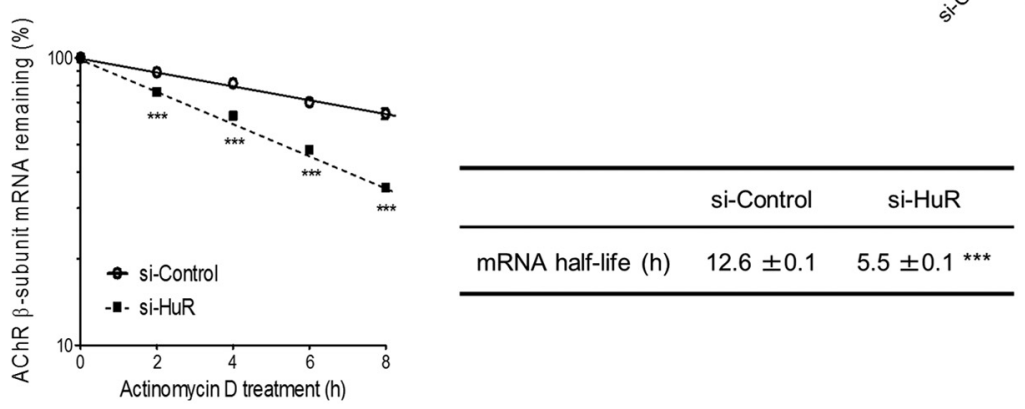

Figure 4. HuR binds and stabilizes endogenous AChR $\beta$-subunit transcripts in cultured myotubes and in vivo. $A$, RIP assays show that HuR interacts with endogenous AChR $\beta$-subunit mRNAs in cultures myotubes. 18S rRNA and lgG were used as controls. B, RIP experiments were performed using innervated (Inn) and denervated (Den) muscles. A representative Western blot confirming the quantity of immunoprecipitated HuR is shown (top, Input and IP). Data show the amount of AChR $\beta$-subunit mRNAs in each immunoprecipitate. Data are mean \pm SEM ( $n=4$ per group). ${ }^{*} p<0.05$, ${ }^{* *} p<0.01$ : significantly different from innervated group and the corresponding lgG group, respectively. C, D, Stability of AChR $\beta$-subunit mRNAs in myotubes transfected with si-HuR. Representative immunoblot ( $\boldsymbol{C}$, left) and quantification ( $\boldsymbol{C}$, middle) of HuR protein content and endogenous mRNA levels of AChR $\beta$-subunit ( , right) after si-HuR transfection. 185 was used as a housekeeping gene for mRNA level and $\alpha$-tubulin as a loading control for protein quantification. After the myoblast transfection and differentiation into myotubes, cells were treated with actinomycin $\mathrm{D}$ ( $5 \mu \mathrm{g}$ $\cdot \mathrm{ml}^{-1}$ ) for 2, 4, 6, and $8 \mathrm{~h}$ and AChR $\beta$-subunit mRNA half-life was measured (D). ${ }^{* *} p<0.001$ : significantly different from si-Control group. Data are presented as percentage of control SEM ( $n=$ $3-5$ independent experiments).

suggesting that such increases could sustain the increase in p38 MAPK phosphorylation seen after denervation.

To evaluate whether MKK6 increases the stability of AChR $\beta$-subunit mRNAs, we also transfected $\mathrm{C} 2 \mathrm{C} 12$ cells with a MKK6-EE constitutively active mutant causing sustained activation of p38 MAPK signaling. Upon overexpression of MKK6-EE, we not only noted an increase $(\sim 73 \%, p<0.01)$ in the phosphorylation of p38 MAPK as expected, but also we observed an increase in AChR $\beta$-subunit mRNA levels $(\sim 46 \%, p<0.05$; Fig. $6 C)$. To determine whether constitutively active p38 MAPK regulates the stability of AChR $\beta$-subunit mRNAs, we also measured the degradation rate of these transcripts in transfected myotubes using actinomycin D. Under these conditions, we observed an increase $(\sim 86 \%, p<0.05)$ in the stability of AChR $\beta$-subunit mRNAs in muscle cells transfected with the constitutively active MKK6-EE mutant.

Finally, skeletal muscle is highly enriched in kinase phosphatases MKP-1 (Misra-Press et al., 1995) and MKP-5 (Theodosiou et al., 1999), known to be critical negative regulators of p38 MAPK signaling. Their contributions to the regulation of $\mathrm{p} 38$ MAPK after skeletal muscle denervation is currently unknown. In attempts to gain additional insights into upstream molecules engaged in p38 MAPK activation after denervation, we focused our attention on these two important kinase phosphatases. Analysis of denervated versus innervated muscles revealed a decrease $(\sim 30 \%, p<0.05)$ in MKP-1 expression after denervation (Fig. $6 D$ ) with no changes in MKP-5 protein levels (Fig. $6 E$ ). Together, these results suggest that the increased activation of p38 MAPK signaling induced by skeletal muscle denervation is at least partly due to the activation of the MKK3 and 6, and a concomitant reduction in the expression of MKP-1.

\section{Discussion}

Transcriptional events have been described as the most important mechanism for regulating AChR mRNAs during myogenic differentiation and at the NMJ. Indeed, during muscle differentiation, AChR promoters are activated through E-boxes (Prody and Merlie, 1991, 1992; Jia et al., 1992; Simon et al., 1992; J. Tang et al., 1994; Bessis et al., 1995; Duclert and Changeux, 1995; Massari and Murre, 2000), which interact with myogenic factors to control transcription (Piette et al., 1990; Macpherson et al., 2006; H. Tang et al., 2006). At the mature NMJ, it was first suggested that neuregulin (NRG), which binds to ErbB receptors on the postsynaptic membrane, activates $\mathrm{AChR}$ gene transcription via the transcription factor GABP, which in turn binds to a regulatory element in AChR promoters termed the N-box (Schaeffer et al., 1998, 2001). However, mice lacking NRG/ErbB signaling express synaptic AChR genes (Escher et al., 2005), indicating that NRG signaling to muscle is not essential for AChR gene transcription. This, is turn, suggests the existence of parallel, yet elusive signaling pathways to control AChR gene transcription at the mature NMJ.

For years, denervation has been widely used as a model to study AChR gene regulation (Evans et al., 1987; Goldman et al., 

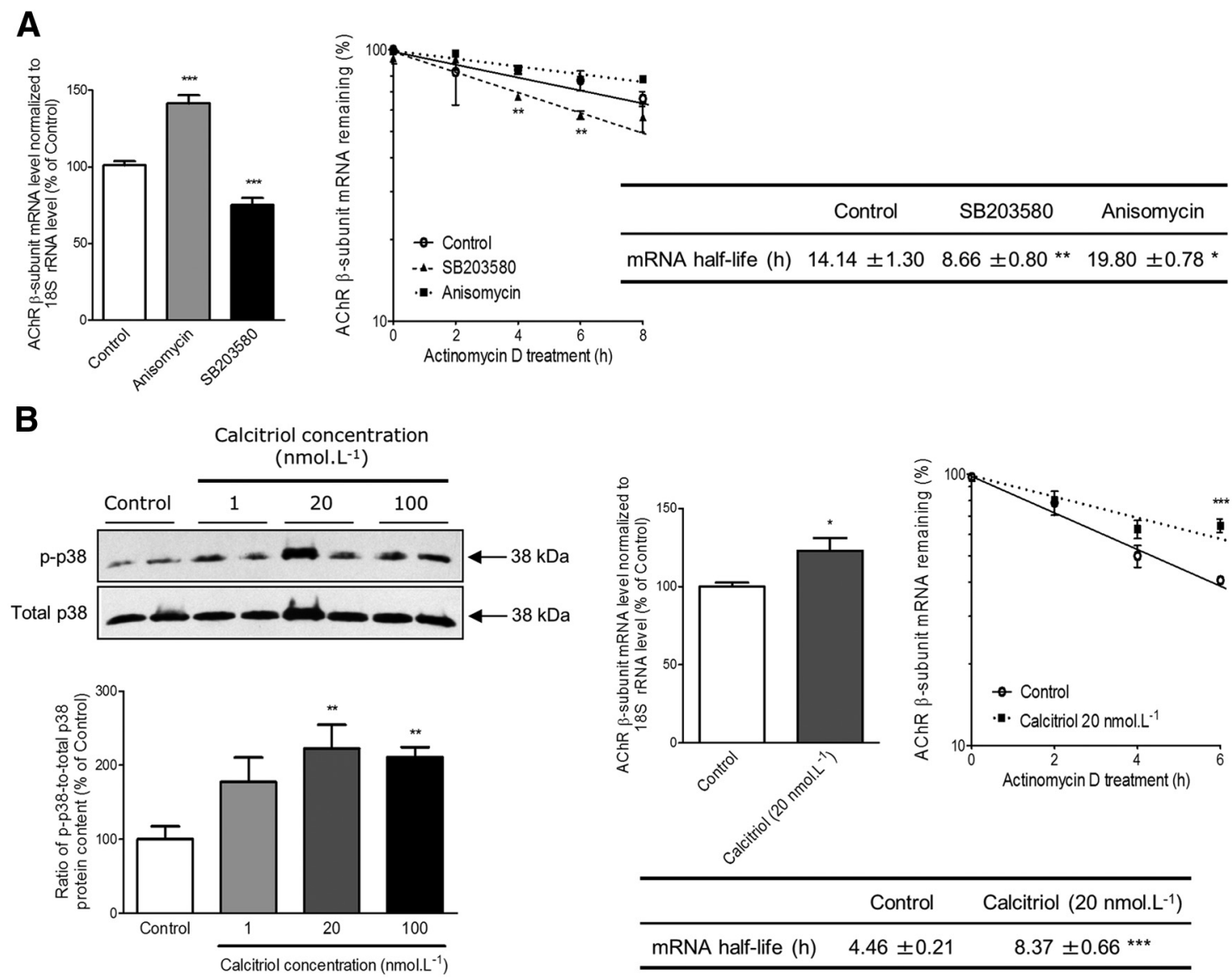

Figure 5. $\mathrm{p} 38 \mathrm{MAPK}$ signaling regulates AChR $\beta$-subunit mRNA stability in vitro. $A$, Levels of AChR $\beta$-subunit mRNA in $3 \mathrm{~d}$ differentiated myotubes treated with the activator of $\mathrm{p} 38 \mathrm{MAPK}$, anisomycin, or its inhibitor, SB203580 (left) for $1 \mathrm{~h}$. Stability of AChR $\beta$-subunit mRNAs in $3 \mathrm{~d}$ differentiated and drug-treated myotubes also treated with actinomycin $\mathrm{D}\left(5 \mu \mathrm{g} \cdot \mathrm{ml}^{-1}\right)$ for $2,4,6$, and $8 \mathrm{~h}$ (middle). AChR $\beta$-subunit mRNA half-life was measured and is shown on the right. $B$, Representative immunoblots of p38 phosphorylation (p-p38) and total p38 protein content (left), and quantification of the ratio p-p38/total p38 (bottom) after $24 \mathrm{~h}$ of calcitriol treatment $\left(1,20\right.$, and $\left.100 \mathrm{nmol} \cdot \mathrm{L}^{-1}\right)$ of $3 \mathrm{~d}$ differentiated myotubes. Levels of AChR $\beta$-subunit mRNA in $3 \mathrm{~d}$ differentiated myotubes treated for $24 \mathrm{~h}$ with calcitriol $\left(20 \mathrm{nmol} \cdot \mathrm{L}^{-1}\right)$. $18 \mathrm{~S}$ was used as housekeeping gene. Stability of $A C \mathrm{Ch} \beta$-subunit $\mathrm{mRNAs}$ in $3 \mathrm{~d}$ differentiated and drug-treated myotubes also treated with actinomycin D $\left(5 \mu \mathrm{g} \cdot \mathrm{ml}^{-1}\right)$ for 2,4 , and $6 \mathrm{~h}$ (right). AChR $\beta$-subunit mRNA half-life was measured and is shown in the table below. ${ }^{*} p<0.05,{ }^{* *} p<0.01,{ }^{* * *} p<0.001$ : significantly different from control group. Data are presented as percentage of control SEM ( $n=3-4$ independent experiments).

1988; Witzemann et al., 1989). Under these conditions, it has also been reported that transcriptional mechanisms regulate AChR gene expression (Schaeffer et al., 2001; Méjat et al., 2003; Kummer et al., 2006). Despite the abundant literature showing the importance of transcription in denervation-induced increases in AChR expression which occurs predominantly in extrasynaptic regions of muscle fibers (Hartzell and Fambrough, 1972; our study), such findings do not rule out that other mechanisms can also be involved. In fact, there is currently a lack of information on the role of post-transcriptional mechanisms in regulating synaptic mRNAs in muscle. Using multiple approaches, we show for the first time that denervation causes an increase in the stability of AChR $\beta$-subunit mRNAs. Moreover, we describe the critical role of the ARE located in the $3^{\prime} \mathrm{UTR}$ of AChR $\beta$-subunit mRNAs in controlling their stability. Such findings are in agreement with indirect evidence obtained by Tsay and Schmidt (1989) showing discordance between transcription and AChR mRNA abundance in denervated muscles (Duclert and Changeux, 1995), and with the notion that it takes more than transcription to regulate the levels and localization of synaptic mRNAs in muscle (Chakkalakal and Jasmin, 2003). Collectively, these data allow us to propose a model in which upon denervation, there is a burst of transcription of genes encoding AChR $\beta$-subunits that is accom- panied by an increase in the stability of AChR $\beta$-subunit mRNAs as to maximize their expression.

Of relevance, our results show that the AChR $\beta$-subunit 3'UTR contains only one ARE which appears to play a critical role in mediating changes in AChR $\beta$-subunit mRNA expression. AREs are known to be key in mediating mRNA decay (Barreau et al., 2005; von Roretz et al., 2011b; Schoenberg and Maquat, 2012) and it has been estimated that $\sim 8 \%$ of mRNAs contain AREs (Bakheet et al., 2006), which demonstrates their importance (Chen and Shyu, 1995; Matoulkova et al., 2012). To mediate their effects on mRNA stability, AREs require interactions with specific RBPs. RBPs can either stabilize or destabilize target transcripts. For instance, AUF-1, TTP, TIA-1, and KSRP are known to typically destabilize mRNAs whereas the Hu family members HuB, $\mathrm{HuC}, \mathrm{HuD}$, and $\mathrm{HuR}$, have marked effects in stabilizing transcripts (Apponi et al., 2011; von Roretz et al., 2011b). The reason that stimulated our interest in HuR is that this RBP is ubiquitously expressed including in muscle (Ma et al., 1996; Gallouzi et al., 2000; van der Giessen et al., 2003). Furthermore, previous work showed that HuR stabilizes MyoD, myogenin, and p21 mRNA levels (Figueroa et al., 2003; van der Giessen et al., 2003), and AChE transcripts in muscle cells (Deschênes-Furry et al., 2005). 
A

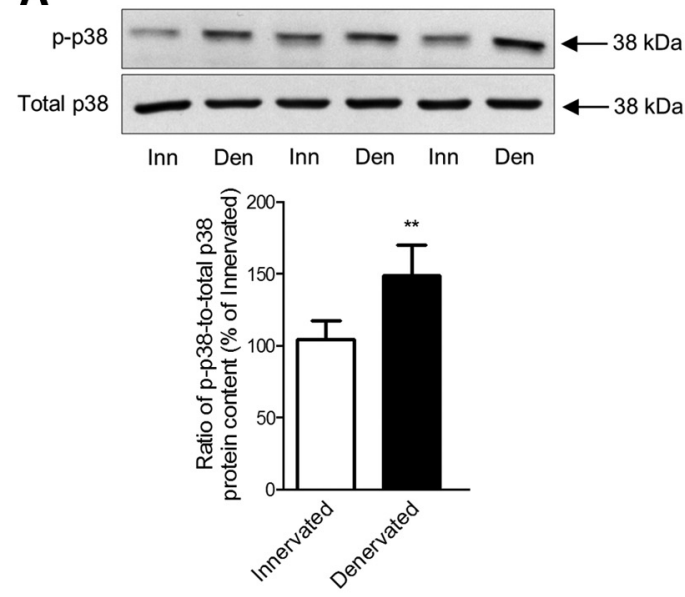

C
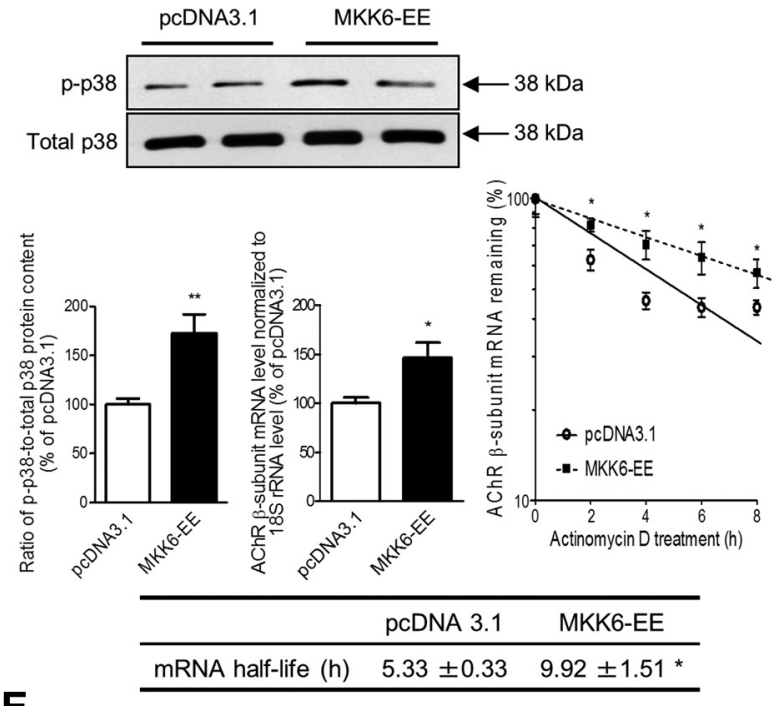

$\mathbf{E}$
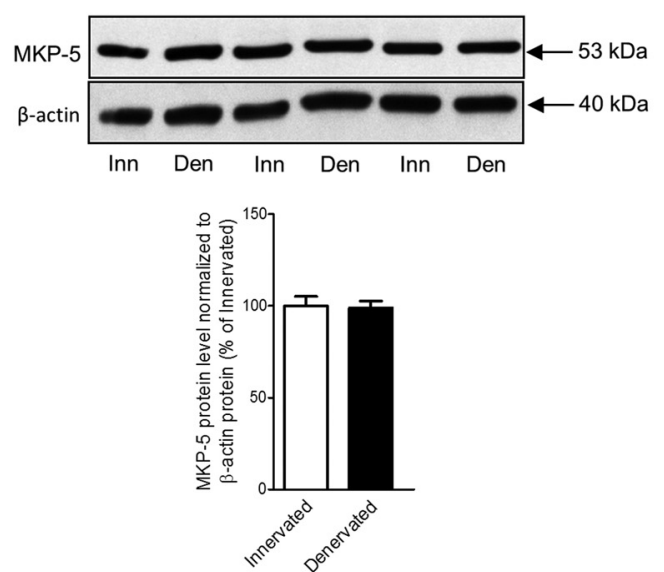

B
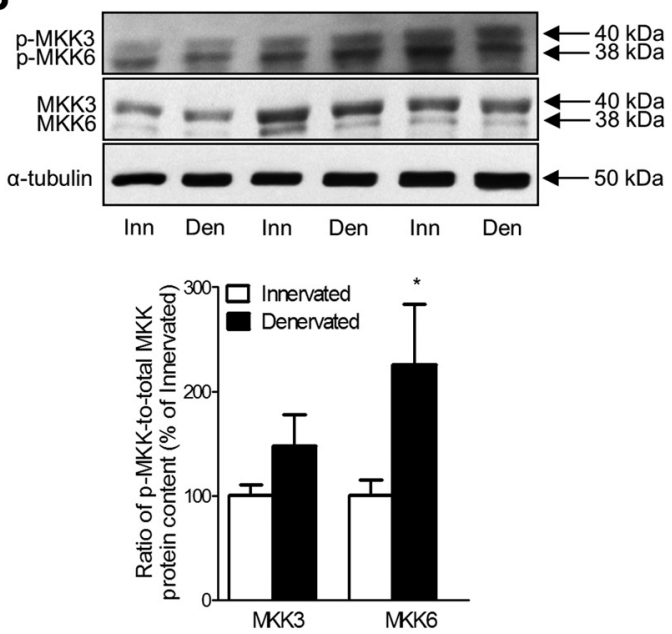

D
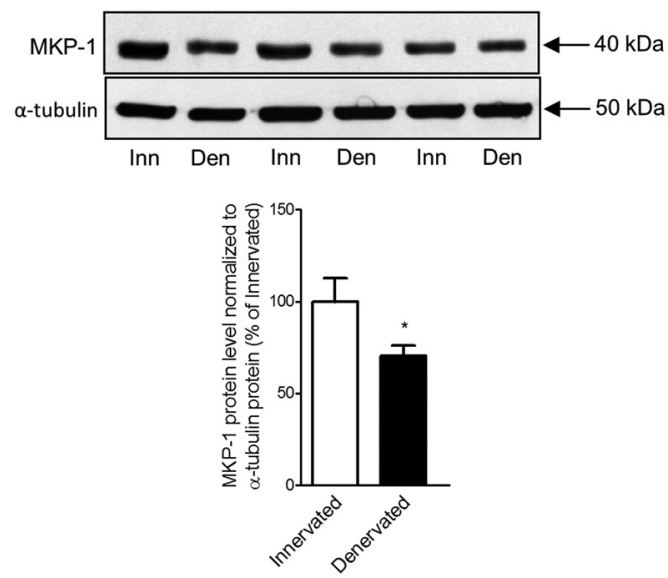

Figure 6. Denervation induces $p 38$ MAPK signaling and regulates AChR $\beta$-subunit mRNA stability. $A$, Representative immunoblots of $p 38$ phosphorylation ( $p$-p 38 ) and total $p 38$ protein content (top), and quantification of the ratio $\mathrm{p}-\mathrm{p} 38 /$ total $\mathrm{p} 38$ (bottom). ${ }^{* *} p<0.01$ : significantly different from the innervated group. $\boldsymbol{B}$, Representative immunoblots of MKK3/MKK6 phosphorylation (p-MKK3 and p-MKK6) and total MKK3/MKK6 protein content (top) and quantification of the ratio p-MKK/total MKK (bottom). $\alpha$-Tubulin was used as a loading control for protein quantification. ${ }^{*} p<0.05$ : significantly different from the innervated group. C, Stability of AChR $\beta$-subunit mRNAs in myotubes after transfection with the constitutively active mutant MKK6-EE. Representative immunoblots and quantification of p-p38 and total p38 protein content and levels of endogenous AChR $\beta$-subunit mRNAs (left). 185 was used as housekeeping gene. Transfected myotubes were treated with actinomycin D $\left(5 \mu \mathrm{g} \cdot \mathrm{ml}^{-1}\right)$ for 2, 4, 6, and $8 \mathrm{~h}$ (top, right) and AChR $\beta$-subunit mRNA half-life was measured and is shown in the table below. ${ }^{*} p<0.05$ and ${ }^{* *} p<0.01$ : significantly different from pcDNA3.1 control group. D, Representative immunoblots of MKP-1 (top) and quantification of MKP-1 protein content (bottom). Protein levels of MKP-1 were standardized against $\alpha$-tubulin. The same membrane was used for MKP-1 and $\alpha$-tubulin. ${ }^{*} p<0.05$ : significantly different from the innervated group. $E$, Representative immunoblots of MKP-5 (top) and quantification of MKP-5 protein content (bottom). Protein levels of MKP-5 were standardized against $\beta$-actin. The same membrane was used for MKP- 5 and $\beta$-actin. Values are mean \pm SEM $(n=4-8$ per group). 
HuR belongs to the Elav-like protein family containing three conserved RNA recognition motifs (Venigalla and Turner, 2012). It is known that HuR shuttles between the nucleus and cytoplasm as myogenic differentiation proceeds (Fan et al., 1997; Peng et al., 1998; Figueroa et al., 2003; van der Giessen et al., 2003). By binding to ARE-containing mRNAs in the nucleus, HuR escorts transcripts through nuclear pores thereby providing protection during and after export to the cytoplasm (Fan and Steitz, 1998). During myogenesis, HuR is cleaved by caspases generating HuRCP1 which binds to and blocks the HuR import factor transportin-2 (von Roretz et al., 2011a), thus facilitating accumulation of HuR in the cytoplasm (Beauchamp et al., 2010). Here, we observed an important increase in HuR following denervation. Additional experiments further revealed that denervation promotes the nuclear-cytoplasmic transport of HuR.

This novel post-transcriptional mechanism that we describe here, may be essential to ensure adequate expression of $\beta$-subunits and hence, of fully formed AChRs. In the absence of HuR, denervated fibers may not be able to synthesize sufficient AChRs to cause ACh supersensitivity, necessary for reinnervation, especially because AChR $\beta$-subunits may be rate-limiting in the assembly of AChRs (Claudio et al., 1989; Saedi et al., 1991). Similarly, one can also envisage that because HuR is important during myogenic differentiation (Figueroa et al., 2003; van der Giessen et al., 2003), its absence would impact synapse formation by limiting the ability of developing muscle fibers to express sufficient levels of AChRs. Given that the AChR $\gamma$ - and $\delta$-subunit mRNAs also contain at least one ARE binding site, one could easily envisage a model of post-transcriptional coregulation of at least these AChR-subunits following denervation. Nevertheless, this coregulation via $\mathrm{HuR}$ would be limited to the $\beta$-, $\gamma$-, and $\delta$-subunits which raises the possibility that additional posttranscriptional mechanisms may be involved in controlling expression of the $\alpha$ - and $\varepsilon$ - subunits.

During myogenic differentiation, phosphorylation of p38 MAPK increases (Galbiati et al., 1999; Zetser et al., 1999; BaezaRaja and Munoz-Canoves, 2004), leading to transcriptional activation of MyoD and MEF2A and C (Ornatsky et al., 1999; Zetser et al., 1999). Furthermore, pharmacological activation of p38 MAPK in motoneurons causes a cytoplasmic accumulation of HuR (Farooq et al., 2009) with subsequent stabilization of target transcripts. We wondered whether p38 MAPK was activated after skeletal muscle denervation. As expected, we show increased phosphorylation of p38 MAPK postdenervation (Evertsson et al., 2014). In addition, we demonstrate that this activation of $\mathrm{p} 38$ MAPK signaling promotes changes in the stability of AChR $\beta$-subunit mRNAs. Such findings raise the question as to the nature of the signaling events involved in the increase of p38 MAPK in denervated muscle. We report for the first time that the p38 MAPK denervation-induced phosphorylation is associated with activation of MKK3/6 and with a concomitant decrease in MKP-1 expression. Previous work has shown that MKP-1 expression is also decreased in hindlimb muscle unloading (MisraPress et al., 1995; Bey et al., 2003) and that muscle atrophy is associated with MKP-1 deficiency (Wu et al., 2006). Together, it appears therefore that denervation triggers an activation of upstream kinases while also inhibiting a known phosphatase, the cumulative impact being an activation of p38 MAPK signaling and redistribution of HuR.

Based on our results, we can depict a model of regulation in which the stability of AChR $\beta$-subunit mRNAs is increased by $\mathrm{HuR}$ following denervation via interaction with an ARE located in the 3'UTR. Denervation causes both an increase in the expres-
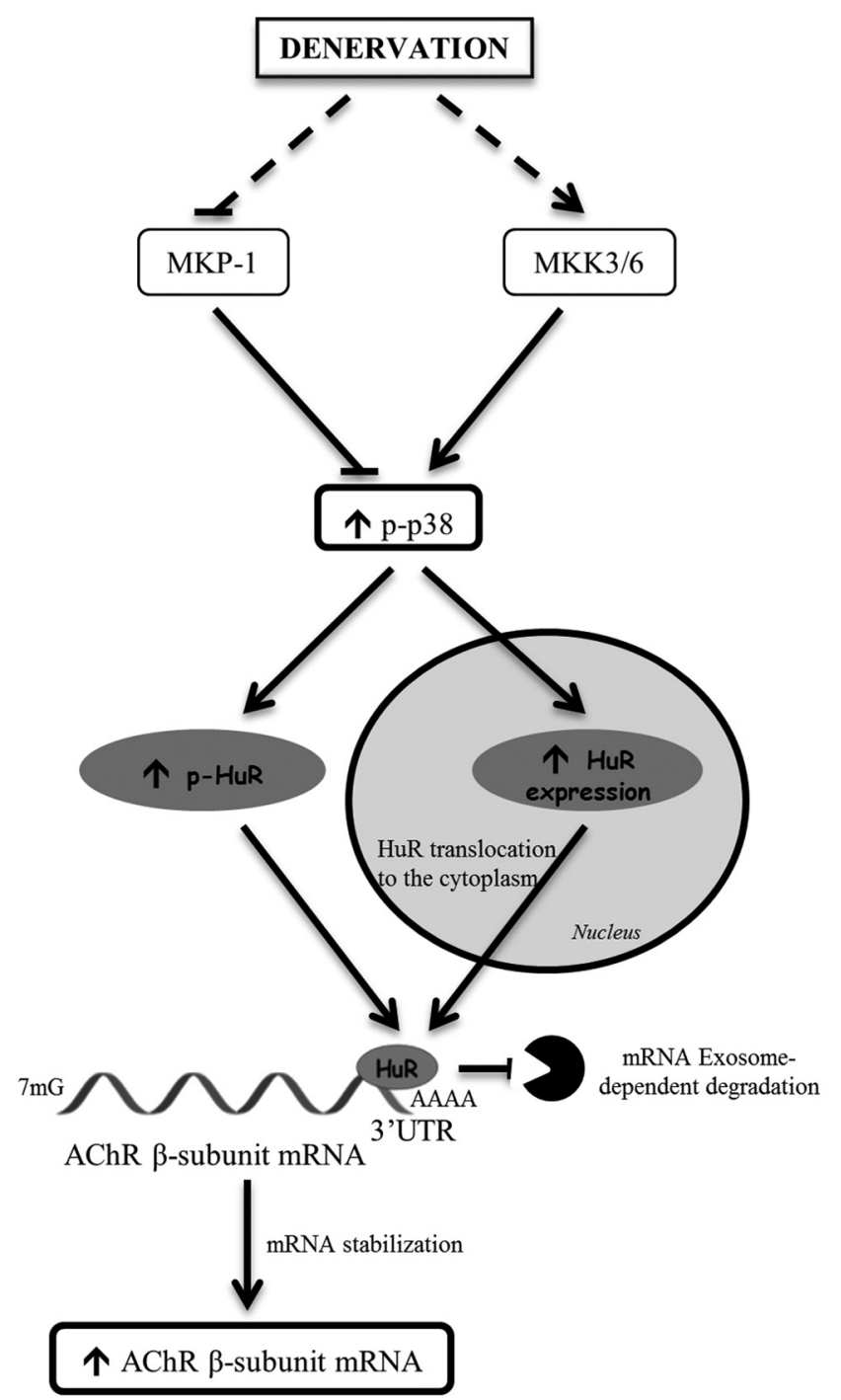

Figure 7. Model of post-transcriptional regulation of $A C h R \beta$-subunit mRNAs following denervation. Skeletal muscle denervation increases the phosphorylation of p38 MAPK through activation of MKK3/6 and inhibition of MKP-1. p38 MAPK activation causes in turn an increased expression of HuR and its phosphorylation thereby promoting greater cytoplasmic localization of HuR. By interacting with the $3^{\prime}$ UTR of AChR $\beta$-subunit mRNAs, HuR stabilizes the transcript which results in an increase in AChR $\beta$-subunit mRNA levels following denervation.

sion of $\mathrm{HuR}$ and in its nuclear-cytoplasmic export. Such translocation of HuR involves p38 MAPK whose activation levels are modulated following denervation by two pathways: an activation of upstream kinases and reduced expression of MKP-1 (Fig. 7). Remaining questions, therefore, concern the mechanisms by which denervation causes activation of MKK $3 / 6$ and inhibition of MKP-1, and whether such signaling changes play a role in other adaptive changes seen in denervated muscles. In this context, Fn14, the receptor of the tumor necrosis factor-related weak inducer of apoptosis (TWEAK), a muscle-wasting cytokine, is markedly increased after denervation (Mittal et al., 2010). Interestingly, TWEAK activates p38 MAPK in myotubes (Li et al., 2009) via MKK $3 / 6$, suggesting a link between denervation, TWEAK/Fn14, and MKK3/6/p38 MAPK. Given the well established role of calcium on AChR expression (Klarsfeld et al., 1989; Huang et al., 1994), one could also envisage a contribution of altered calcium dynamics as a trigger for activating p38 signaling in denervated muscle. 
Our results do not preclude that the enhanced stability of AChR $\beta$-subunit mRNAs after denervation involves additional RBPs and/or micro-RNAs (Briata et al., 2005; Linker et al., 2005; Amirouche et al., 2013b). Therefore, the results presented here are only the beginning if the ultimate goal is to gain a full understanding of post-transcriptional events involved in controlling the stability of AChR $\beta$-subunit transcripts and other AChR subunit mRNAs. In this context, studying the expression and localization of RBP in skeletal muscle with a particular emphasis on the NMJ will not only yield novel findings related to events controlling the formation and maintenance of this synapse, but in addition, such studies could lead to the development of RNAbased therapeutics for neuromuscular disorders.

\section{References}

Altiok N, Altiok S, Changeux JP (1997) Heregulin-stimulated acetylcholine receptor gene expression in muscle: requirement for MAP kinase and evidence for a parallel inhibitory pathway independent of electrical activity. EMBO J 16:717-725. CrossRef Medline

Amirouche A, Tadesse H, Lunde JA, Bélanger G, Côté J, Jasmin BJ (2013a) Activation of p38 signaling increases utrophin A expression in skeletal muscle via the RNA-binding protein KSRP and inhibition of AU-rich element-mediated mRNA decay: implications for novel DMD therapeutics. Hum Mol Genet 22:3093-3111. CrossRef Medline

Amirouche A, Tadesse H, Miura P, Bélanger G, Lunde JA, Côté J, Jasmin BJ (2013b) Converging pathways involving microRNA-206 and the RNAbinding protein KSRP control post-transcriptionally utrophin A expression in skeletal muscle. Nucleic Acids Res 42:3982-3997. Medline

Apponi LH, Corbett AH, Pavlath GK (2011) RNA-binding proteins and gene regulation in myogenesis. Trends Pharmacol Sci 32:652-658. CrossRef Medline

Baeza-Raja B， Muñoz-Cánoves P (2004) p38 MAPK-induced nuclear factor-kappaB activity is required for skeletal muscle differentiation: role of interleukin-6. Mol Biol Cell 15:2013-2026. CrossRef Medline

Bakheet T, Williams BR, Khabar KS (2006) ARED 3.0: the large and diverse AU-rich transcriptome. Nucleic Acids Res 34:D111-D114. CrossRef Medline

Barreau C, Paillard L, Osborne HB (2005) AU-rich elements and associated factors: are there unifying principles? Nucleic Acids Res 33:7138-7150. CrossRef Medline

Beauchamp P, Nassif C, Hillock S, van der Giessen K, von Roretz C, Jasmin BJ, Gallouzi IE (2010) The cleavage of HuR interferes with its transportin2-mediated nuclear import and promotes muscle fiber formation. Cell Death Differ 17:1588-1599. CrossRef Medline

Bessis A, Salmon AM, Zoli M, Le Novère N, Picciotto M, Changeux JP (1995) Promoter elements conferring neuron-specific expression of the beta 2 -subunit of the neuronal nicotinic acetylcholine receptor studied in vitro and in transgenic mice. Neuroscience 69:807-819. CrossRef Medline

Bey L, Akunuri N, Zhao P, Hoffman EP, Hamilton DG, Hamilton MT (2003) Patterns of global gene expression in rat skeletal muscle during unloading and low-intensity ambulatory activity. Physiol Genomics 13:157-167. CrossRef Medline

Borges LS, Yechikhov S, Lee YI, Rudell JB, Friese MB, Burden SJ, Ferns MJ (2008) Identification of a motif in the acetylcholine receptor beta subunit whose phosphorylation regulates rapsyn association and postsynaptic receptor localization. J Neurosci 28:11468-11476. CrossRef Medline

Briata P, Forcales SV, Ponassi M, Corte G, Chen CY, Karin M, Puri PL, Gherzi R (2005) p38-dependent phosphorylation of the mRNA decaypromoting factor KSRP controls the stability of select myogenic transcripts. Mol Cell 20:891-903. CrossRef Medline

Buitrago CG, Ronda AC, de Boland AR, Boland R (2006) MAP kinases p38 and JNK are activated by the steroid hormone 1alpha,25(OH)2-vitamin D3 in the C2C12 muscle cell line. J Cell Biochem 97:698-708. CrossRef Medline

Buitrago C, Pardo VG, Boland R (2013) Role of VDR in 1alpha,25dihydroxyvitamin D3-dependent non-genomic activation of MAPKs, Src and Akt in skeletal muscle cells. J Steroid Biochem Mol Biol 136:125-130. CrossRef Medline

Buonanno A, Merlie JP (1986) Transcriptional regulation of nicotinic acetylcholine receptor genes during muscle development. J Biol Chem 261: 11452-11455. Medline
Burden S, Yarden Y (1997) Neuregulins and their receptors: a versatile signaling module in organogenesis and oncogenesis. Neuron 18:847-855. CrossRef Medline

Chakkalakal JV, Jasmin BJ (2003) Localizing synaptic mRNAs at the neuromuscular junction: it takes more than transcription. Bioessays 25:25-31. CrossRef Medline

Chakkalakal JV, Miura P, Bélanger G, Michel RN, Jasmin BJ (2008) Modulation of utrophin A mRNA stability in fast versus slow muscles via an AU-rich element and calcineurin signaling. Nucleic Acids Res 36:826838. CrossRef Medline

Chen CY, Shyu AB (1995) AU-rich elements: characterization and importance in mRNA degradation. Trends Biochem Sci 20:465-470. CrossRef Medline

Claudio T, Paulson HL, Green WN, Ross AF, Hartman DS, Hayden D (1989) Fibroblasts transfected with Torpedo acetylcholine receptor beta-, gamma-, and delta-subunit cDNAs express functional receptors when infected with a retroviral alpha recombinant. J Cell Biol 108:2277-2290. CrossRef Medline

Deschênes-Furry J, Bélanger G, Mwanjewe J, Lunde JA, Parks RJ, PerroneBizzozero N, Jasmin BJ (2005) The RNA-binding protein HuR binds to acetylcholinesterase transcripts and regulates their expression in differentiating skeletal muscle cells. J Biol Chem 280:25361-25368. CrossRef Medline

Dimauro I, Pearson T, Caporossi D, Jackson MJ (2012) A simple protocol for the subcellular fractionation of skeletal muscle cells and tissue. BMC Res Notes 5:513. CrossRef Medline

Duclert A, Changeux JP (1995) Acetylcholine receptor gene expression at the developing neuromuscular junction. Physiol Rev 75:339-368. Medline

Duclert A, Savatier N, Schaeffer L, Changeux JP (1996) Identification of an element crucial for the sub-synaptic expression of the acetylcholine receptor epsilon-subunit gene. J Biol Chem 271:17433-17438. CrossRef Medline

Eftimie R, Brenner HR, Buonanno A (1991) Myogenin and MyoD join a family of skeletal muscle genes regulated by electrical activity. Proc Natl Acad Sci U S A 88:1349-1353. CrossRef Medline

Escher P, Lacazette E, Courtet M, Blindenbacher A, Landmann L, Bezakova G, Lloyd KC, Mueller U, Brenner HR (2005) Synapses form in skeletal muscles lacking neuregulin receptors. Science 308:1920-1923. CrossRef Medline

Evans S, Goldman D, Heinemann S, Patrick J (1987) Muscle acetylcholine receptor biosynthesis: regulation by transcript availability. J Biol Chem 262:4911-4916. Medline

Evertsson K, Fjällström AK, Norrby M, Tågerud S (2014) p38 Mitogenactivated protein kinase and mitogen-activated protein kinase-activated protein kinase 2 (MK2) signaling in atrophic and hypertrophic denervated mouse skeletal muscle. J Mol Signal 9:2. CrossRef Medline

Fan XC, Steitz JA (1998) HNS, a nuclear-cytoplasmic shuttling sequence in HuR. Proc Natl Acad Sci U S A 95:15293-15298. CrossRef Medline

Fan XC, Myer VE, Steitz JA (1997) AU-rich elements target small nuclear RNAs as well as mRNAs for rapid degradation. Genes Dev 11:2557-2568. CrossRef Medline

Farooq F, Balabanian S, Liu X, Holcik M, MacKenzie A (2009) p38 Mitogen-activated protein kinase stabilizes SMN mRNA through RNA binding protein HuR. Hum Mol Genet 18:4035-4045. CrossRef Medline

Figueroa A, Cuadrado A, Fan J, Atasoy U, Muscat GE, Muñoz-Canoves P, Gorospe M, Muñoz A (2003) Role of HuR in skeletal myogenesis through coordinate regulation of muscle differentiation genes. Mol Cell Biol 23:4991-5004. CrossRef Medline

Fischbach GD, Rosen KM (1997) ARIA: a neuromuscular junction neuregulin. Annu Rev Neurosci 20:429-458. CrossRef Medline

Friese MB, Blagden CS, Burden SJ (2007) Synaptic differentiation is defective in mice lacking acetylcholine receptor beta-subunit tyrosine phosphorylation. Development 134:4167-4176. CrossRef Medline

Galbiati F, Volonte D, Engelman JA, Scherer PE, Lisanti MP (1999) Targeted down-regulation of caveolin-3 is sufficient to inhibit myotube formation in differentiating $\mathrm{C} 2 \mathrm{C} 12$ myoblasts: transient activation of $\mathrm{p} 38$ mitogen-activated protein kinase is required for induction of caveolin-3 expression and subsequent myotube formation. J Biol Chem 274:3031530321. CrossRef Medline

Gallouzi IE, Brennan CM, Stenberg MG, Swanson MS, Eversole A, Maizels N, 
Steitz JA (2000) HuR binding to cytoplasmic mRNA is perturbed by heat shock. Proc Natl Acad Sci U S A 97:3073-3078. CrossRef Medline

Goldman D, Brenner HR, Heinemann S (1988) Acetylcholine receptor alpha-, beta-, gamma-, and delta-subunit mRNA levels are regulated by muscle activity. Neuron 1:329-333. CrossRef Medline

Gruber AR, Fallmann J, Kratochvill F, Kovarik P, Hofacker IL (2011) AREsite: a database for the comprehensive investigation of AU-rich elements. Nucleic Acids Res 39:D66-D69. CrossRef Medline

Hartzell HC, Fambrough DM (1972) Acetylcholine receptors. Distribution and extrajunctional density in rat diaphragm after denervation correlated with acetylcholine sensitivity. J Gen Physiol 60:248-262. CrossRef Medline

Huang CF, Flucher BE, Schmidt MM, Stroud SK, Schmidt J (1994) Depolarization-transcription signals in skeletal muscle use calcium flux through L channels, but bypass the sarcoplasmic reticulum. Neuron 13: 167-177. CrossRef Medline

Jia HT, Tsay HJ, Schmidt J (1992) Analysis of binding and activating functions of the chick muscle acetylcholine receptor gamma-subunit upstream sequence. Cell Mol Neurobiol 12:241-258. CrossRef Medline

Klarsfeld A, Laufer R, Fontaine B, Devillers-Thiéry A, Dubreuil C, Changeux JP (1989) Regulation of muscle AChR alpha subunit gene expression by electrical activity: involvement of protein kinase $\mathrm{C}$ and $\mathrm{Ca} 2+$. Neuron 2:1229-1236. CrossRef Medline

Koike S, Schaeffer L, Changeux JP (1995) Identification of a DNA element determining synaptic expression of the mouse acetylcholine receptor delta-subunit gene. Proc Natl Acad Sci U S A 92:10624-10628. CrossRef Medline

Kummer TT, Misgeld T, Sanes JR (2006) Assembly of the postsynaptic membrane at the neuromuscular junction: paradigm lost. Curr Opin Neurobiol 16:74-82. CrossRef Medline

Li H, Mittal A, Paul PK, Kumar M, Srivastava DS, Tyagi SC, Kumar A (2009) Tumor necrosis factor-related weak inducer of apoptosis augments matrix metalloproteinase 9 (MMP-9) production in skeletal muscle through the activation of nuclear factor-kappaB-inducing kinase and p38 mitogen-activated protein kinase: a potential role of MMP-9 in myopathy. J Biol Chem 284:4439-4450. CrossRef Medline

Linker K, Pautz A, Fechir M, Hubrich T, Greeve J, Kleinert H (2005) Involvement of KSRP in the post-transcriptional regulation of human iNOS expression-complex interplay of KSRP with TTP and HuR. Nucleic Acids Res 33:4813-4827. CrossRef Medline

Lomo T, Westgaard RH (1975) Further studies on the control of ACh sensitivity by muscle activity in the rat. J Physiol 252:603-626. CrossRef Medline

Ma WJ, Cheng S, Campbell C, Wright A, Furneaux H (1996) Cloning and characterization of HuR, a ubiquitously expressed Elav-like protein. J Biol Chem 271:8144-8151. CrossRef Medline

Macpherson PC, Cieslak D, Goldman D (2006) Myogenin-dependent nAChR clustering in aneural myotubes. Mol Cell Neurosci 31:649-660. CrossRef Medline

Maltin CA, Delday MI, Campbell GP, Hesketh JE (1993) Clenbuterol mimics effects of innervation on myogenic regulatory factor expression. Am J Physiol 265:E176-178. Medline

Massari ME, Murre C (2000) Helix-loop-helix proteins: regulators of transcription in eucaryotic organisms. Mol Cell Biol 20:429-440. CrossRef Medline

Matoulkova E, Michalova E, Vojtesek B, Hrstka R (2012) The role of the 3' untranslated region in post-transcriptional regulation of protein expression in mammalian cells. RNA Biol 9:563-576. CrossRef Medline

Méjat A, Ravel-Chapuis A, Vandromme M, Schaeffer L (2003) Synapsespecific gene expression at the neuromuscular junction. Ann N Y Acad Sci 998:53-65. CrossRef Medline

Merlie JP, Isenberg KE, Russell SD, Sanes JR (1984) Denervation supersensitivity in skeletal muscle: analysis with a cloned cDNA probe. J Cell Biol 99:332-335. CrossRef Medline

Michel RN, Vu CQ, Tetzlaff W, Jasmin BJ (1994) Neural regulation of acetylcholinesterase mRNAs at mammalian neuromuscular synapses. J Cell Biol 127:1061-1069. CrossRef Medline

Mishina M, Takai T, Imoto K, Noda M, Takahashi T, Numa S, Methfessel C, Sakmann B (1986) Molecular distinction between fetal and adult forms of muscle acetylcholine receptor. Nature 321:406-411. CrossRef Medline

Misra-Press A, Rim CS, Yao H, Roberson MS, Stork PJ (1995) A novel mitogen-activated protein kinase phosphatase: structure, expression, and regulation. J Biol Chem 270:14587-14596. CrossRef Medline
Missias AC, Chu GC, Klocke BJ, Sanes JR, Merlie JP (1996) Maturation of the acetylcholine receptor in skeletal muscle: regulation of the AChR gamma-to-epsilon switch. Dev Biol 179:223-238. CrossRef Medline

Mittal A, Bhatnagar S, Kumar A, Lach-Trifilieff E, Wauters S, Li H, Makonchuk DY, Glass DJ, Kumar A (2010) The TWEAK-Fn14 system is a critical regulator of denervation-induced skeletal muscle atrophy in mice. J Cell Biol 188:833-849. CrossRef Medline

Nakao R, Yamamoto S, Yasumoto Y, Kadota K, Oishi K (2015) Impact of denervation-induced muscle atrophy on housekeeping gene expression in mice. Muscle Nerve 51:276-281. CrossRef Medline

Nechama M, Ben-Dov IZ, Briata P, Gherzi R, Naveh-Many T (2008) The mRNA decay promoting factor K-homology splicing regulator protein post-transcriptionally determines parathyroid hormone mRNA levels. FASEB J 22:3458-3468. CrossRef Medline

Neville CM, Choe YH, Lee YS, Spinner D, Tsay HJ, Schmidt J (1998) The E protein CTF4 and acetylcholine receptor expression in development and denervation supersensitivity. J Biol Chem 273:14046-14052. CrossRef Medline

Ornatsky OI, Cox DM, Tangirala P, Andreucci JJ, Quinn ZA, Wrana JL, Prywes R, Yu YT, McDermott JC (1999) Post-translational control of the MEF2A transcriptional regulatory protein. Nucleic Acids Res 27: 2646-2654. CrossRef Medline

Peng SS, Chen CY, Xu N, Shyu AB (1998) RNA stabilization by the AU-rich element binding protein, HuR, an ELAV protein. EMBO J 17:3461-3470. CrossRef Medline

Piette J, Bessereau JL, Huchet M, Changeux JP (1990) Two adjacent MyoD1-binding sites regulate expression of the acetylcholine receptor alpha-subunit gene. Nature 345:353-355. CrossRef Medline

Prody CA, Merlie JP (1991) A developmental and tissue-specific enhancer in the mouse skeletal muscle acetylcholine receptor alpha-subunit gene regulated by myogenic factors. J Biol Chem 266:22588-22596. Medline

Prody CA, Merlie JP (1992) The 5'-flanking region of the mouse muscle nicotinic acetylcholine receptor beta subunit gene promotes expression in cultured muscle cells and is activated by MRF4, myogenin and myoD. Nucleic Acids Res 20:2367-2372. CrossRef Medline

Quiram PA, Ohno K, Milone M, Patterson MC, Pruitt NJ, Brengman JM, Sine SM, Engel AG (1999) Mutation causing congenital myasthenia reveals acetylcholine receptor beta/delta subunit interaction essential for assembly. J Clin Invest 104:1403-1410. CrossRef Medline

Ronda AC, Buitrago C, Colicheo A, de Boland AR, Roldán E, Boland R (2007) Activation of MAPKs by 1alpha,25(OH)2-Vitamin D3 and 17beta-estradiol in skeletal muscle cells leads to phosphorylation of Elk-1 and CREB transcription factors. J Steroid Biochem Mol Biol 103:462466. CrossRef Medline

Ross J (1995) mRNA stability in mammalian cells. Microbiol Rev 59:423450. Medline

Rudell JB, Ferns MJ (2013) Regulation of muscle acetylcholine receptor turnover by beta subunit tyrosine phosphorylation. Dev Neurobiol 73: 399-410. CrossRef Medline

Saedi MS, Conroy WG, Lindstrom J (1991) Assembly of Torpedo acetylcholine receptors in Xenopus oocytes. J Cell Biol 112:1007-1015. CrossRef Medline

Sandrock AW Jr, Dryer SE, Rosen KM, Gozani SN, Kramer R, Theill LE, Fischbach GD (1997) Maintenance of acetylcholine receptor number by neuregulins at the neuromuscular junction in vivo. Science 276:599-603. CrossRef Medline

Sanes JR, Lichtman JW (2001) Induction, assembly, maturation and maintenance of a postsynaptic apparatus. Nat Rev Neurosci 2:791-805. CrossRef Medline

Schaeffer L, Duclert N, Huchet-Dymanus M, Changeux JP (1998) Implication of a multisubunit Ets-related transcription factor in synaptic expression of the nicotinic acetylcholine receptor. EMBO J 17:3078-3090. CrossRef Medline

Schaeffer L, de Kerchove d'Exaerde A, Changeux JP (2001) Targeting transcription to the neuromuscular synapse. Neuron 31:15-22. CrossRef Medline

Schoenberg DR, Maquat LE (2012) Regulation of cytoplasmic mRNA decay. Nat Rev Genet 13:246-259. CrossRef Medline

Simon AM, Hoppe P, Burden SJ (1992) Spatial restriction of AChR gene expression to subsynaptic nuclei. Development 114:545-553. Medline

Siu PM, Alway SE (2005) Mitochondria-associated apoptotic signalling in denervated rat skeletal muscle. J Physiol 565:309-323. CrossRef Medline 
Siu PM, Alway SE (2006) Deficiency of the Bax gene attenuates denervationinduced apoptosis. Apoptosis 11:967-981. CrossRef Medline

Tang H, Veldman MB, Goldman D (2006) Characterization of a musclespecific enhancer in human MuSK promoter reveals the essential role of myogenin in controlling activity-dependent gene regulation. J Biol Chem 281:3943-3953. CrossRef Medline

Tang J, Jo SA, Burden SJ (1994) Separate pathways for synapse-specific and electrical activity-dependent gene expression in skeletal muscle. Development 120:1799-1804. Medline

Tansey MG, Chu GC, Merlie JP (1996) ARIA/HRG regulates AChR epsilon subunit gene expression at the neuromuscular synapse via activation of phosphatidylinositol 3-kinase and Ras/MAPK pathway. J Cell Biol 134: 465-476. CrossRef Medline

Theodosiou A, Smith A, Gillieron C, Arkinstall S, Ashworth A (1999) MKP5, a new member of the MAP kinase phosphatase family, which selectively dephosphorylates stress-activated kinases. Oncogene 18:69816988. CrossRef Medline

Tsay HJ, Schmidt J (1989) Skeletal muscle denervation activates acetylcholine receptor genes. J Cell Biol 108:1523-1526. CrossRef Medline

van der Giessen K, Di-Marco S, Clair E, Gallouzi IE (2003) RNAi-mediated HuR depletion leads to the inhibition of muscle cell differentiation. J Biol Chem 278:47119-47128. CrossRef Medline

Vandesompele J, De Preter K, Pattyn F, Poppe B, Van Roy N, De Paepe A, Speleman F (2002) Accurate normalization of real-time quantitative RT-PCR data by geometric averaging of multiple internal control genes. Genome Biol 3:RESEARCH0034. CrossRef Medline

Venigalla RK, Turner M (2012) RNA-binding proteins as a point of convergence of the PI3K and p38 MAPK pathways. Front Immunol 3:398. CrossRef Medline von Roretz C, Macri AM, Gallouzi IE (2011a) Transportin 2 regulates apoptosis through the RNA-binding protein HuR. J Biol Chem 286:2598325991. CrossRef Medline

von Roretz C, Di Marco S, Mazroui R, Gallouzi IE (2011b) Turnover of AU-rich-containing mRNAs during stress: a matter of survival. Wiley Interdiscip Rev RNA 2:336-347. CrossRef Medline

Wang W, Furneaux H, Cheng H, Caldwell MC, Hutter D, Liu Y, Holbrook N, Gorospe M (2000) HuR regulates p21 mRNA stabilization by UV light. Mol Cell Biol 20:760-769. CrossRef Medline

Willmann R, Fuhrer C (2002) Neuromuscular synaptogenesis: clustering of acetylcholine receptors revisited. Cell Mol Life Sci 59:1296-1316. CrossRef Medline

Witzemann V (1989) Control of acetylcholine receptors in skeletal muscle. J Protein Chem 8:333-335. CrossRef Medline

Witzemann V, Sakmann B (1991) Differential regulation of MyoD and myogenin mRNA levels by nerve induced muscle activity. FEBS Lett 282: 259-264. CrossRef Medline

Witzemann V, Barg B, Criado M, Stein E, Sakmann B (1989) Developmental regulation of five subunit specific mRNAs encoding acetylcholine receptor subtypes in rat muscle. FEBS Lett 242:419-424. CrossRef Medline

Wu JJ, Roth RJ, Anderson EJ, Hong EG, Lee MK, Choi CS, Neufer PD, Shulman GI, Kim JK, Bennett AM (2006) Mice lacking MAP kinase phosphatase- 1 have enhanced MAP kinase activity and resistance to dietinduced obesity. Cell Metab 4:61-73. CrossRef Medline

Zetser A, Gredinger E, Bengal E (1999) p38 Mitogen-activated protein kinase pathway promotes skeletal muscle differentiation: participation of the Mef2c transcription factor. J Biol Chem 274:5193-5200. CrossRef Medline 